\title{
A Structural Model for Employee Commitment in Iranian State Organizations
}

Mehdi Hassankhani ${ }^{1} \mathrm{Ph}$. D. Student, Department of Public Administration, Qazvin Branch, Islamic Azad University, Iran.

Farajollah Rahnavard ${ }^{2}$ Associate Professor, Department of Public Administration, Institute for Management and Planning Studies, Tehran, Iran (Corresponding Author).

Habibollah Taherpour ${ }^{3}$ Assistant Professor, Department of Public Administration, Institute for Management and Planning Studies, Tehran, Iran.

Nasser Hamidi ${ }^{4}$ Associate Professor, Department Industrial Management, Qazvin Branch,Islamic Azad University, Iran.

\begin{abstract}
Employee commitment, sometimes called work involvement/ belongingness/ engagement, materializes when people have interest in their job, enjoy doing it and try harder to accomplish it. This study aims to investigate the effective factors which can enhance the commitment of employees at individual, group and organizational levels. It also intends to identify and reach a model for the relations among variables. Using structural equations model, data were collected from 65 Iranian state organizations. Findings show that at an organizational level such factors as organizational structure, organizational support, organizational culture, compensation; at group level such factors as effective leadership, pleasant work environment, employee participation, organizational trust, constructive feedback, role transparency; and at individual level such factors as job security, work autonomy, internal motivation, organizational commitment, perceived organizational justice, religious commitment, and extraversion have an impact on employee commitment.
\end{abstract}

Keywords: Employee Commitment, Organizational Support, Organizational Trust, Internal Motivation, Work Compensation.

1.m.hgassankhani@ bankmellat.ir

2.f.rahnavard@imps.ac.ir

3.h.taherpour@imps.ac.ir

4.nhamidi@qiau.ac.ir 


\section{عنوان مقاله: مدل ساختارى التزام كاركنان در سازمانهاى

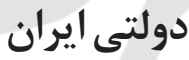

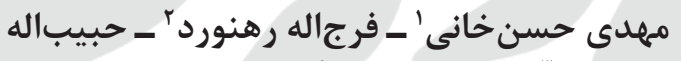

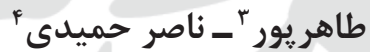

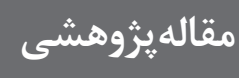

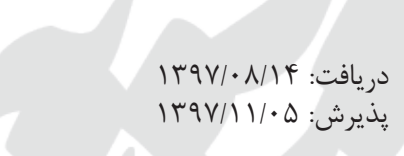

\section{جكيل:}

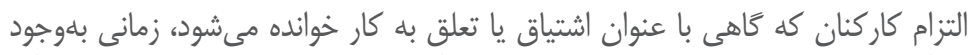

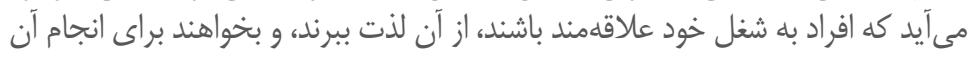

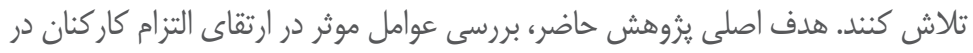

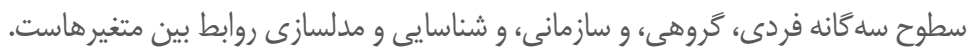

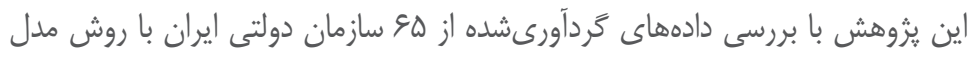

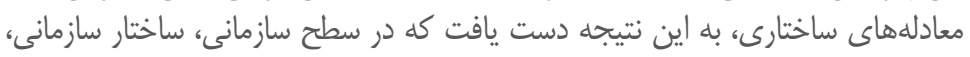

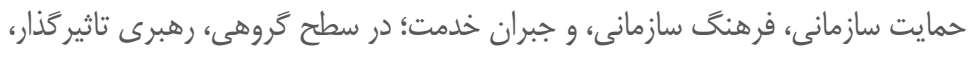

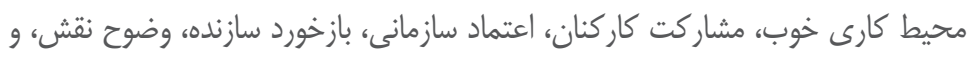

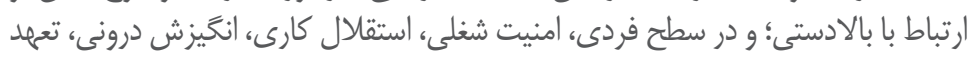

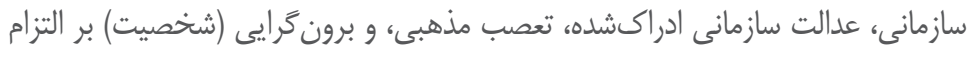

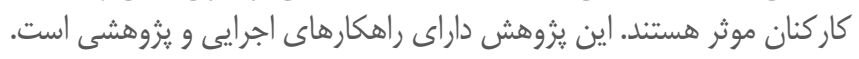
كليدوازهها: التزام كار كنان، حمايت سازمانى، اعتماد سازمانى، انخيزش

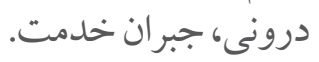
m.hgassankhani@bankmellat.ir

ا. دانشجوى دكترى، گروه مديريت دولتى، واحد قزوين، دانشخاه آزاد اسلامى، قزوين، ايران. r. دانشيار، گروه مديريت دولتى، موسسه عالى آموزش و بثرهش مديريت و برنامهريزى، تهران، ايران (نو يسنده

f.rahnavard@imps.ac.ir

س. استاديار، گرووه مديريت دولتى، موسسه عالى آموزش و بثزوهش مديريت و برنامهريزى، تهران، ايران. h.taherpour@imps.ac.ir

nhamidi@qiau.ac.ir

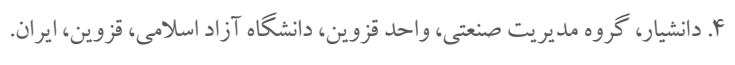




\section{مقدمه}

سير تحول نظريههاى مديريت دولتى نشان مىدهد كه ديدمانهاى مديريت دولتى از مديريت دولتى نوين به سوى خدمات دولتى نوين و حاكميت خوب حركت كرده است. همجنين، يِيشرفت

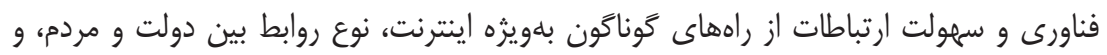

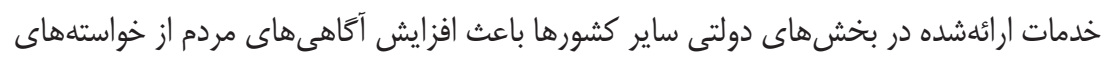

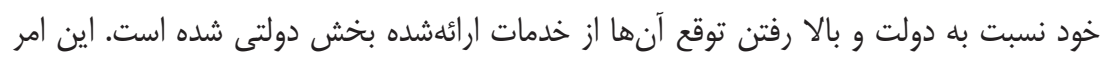
باعث مىشود كه سازمانهاى دولتى به دنبال ارائه خدمات باكيفيت و مطلوب باشند (دنهارت، •مسا(). براى ارائه جنين خدماتى، سازمانهاى دولتى به دنبال منابع انسانى كارامد و اخلاقمدار

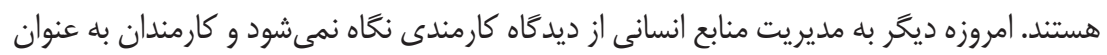
سرمايه انسانى در نظرگرفته مىشوند. از سوى ديخر، مسئوليتهاى مديريت منابع انسانى با تغيير جوامع تغيير ييدا كرده و سازمانهاى دولتى و غيرانتفاعى با قالشهاى جدى اقتصادى، تغيير در قوانين، و تغييرهاى اجتماعى، فرهنگى، و آموزشى مواجه شدهاند. بنابراين، بايد از راهبردهاى منابع

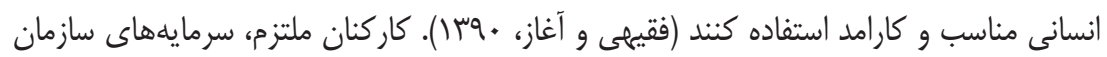
هستند و نقش بسيار مهمى در كسب مزيتهاى رقابتى دارند. سازمانها بايد بر التزام كاركنان به عنوان يك راهبرد نويدبخش متمركز شوند تا بدين وسيله بهروروى سازمان را افزايش دهند

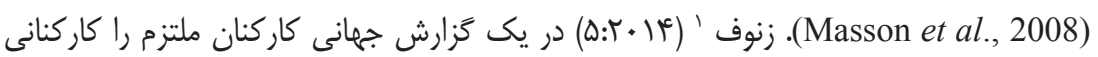
معرفى مى كند كه \ا. براى ماندن در سازمان برنامه دارند و مىدانند به دنبال بهدست آوردن

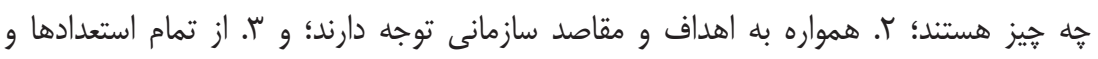
ظرفيتهاى خود براى راهنمايى ديخران در جهت موفقيت سازمان استفاده مىنماينده. از نظر باكر

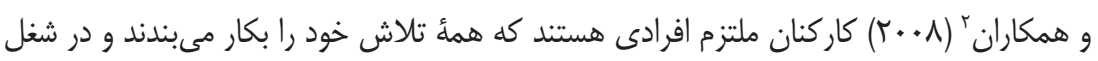
خود بسيار مسلط و متخصص هستند. در حالى كه كاركنان ناملتزم كسانى هستند كه انخيزهُ يايينى در كار دارند و انرزى جندانى براى سخت كار كردن ندارند و مشتاق به كار نيستند.

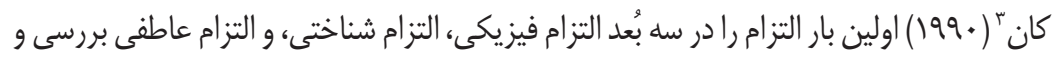

1. Zenoff

2. Bakker et al

3. Kahn 
Krishnan \& Singh, 2010;) تعريف عملياتى كرد. در يى آن، يزووهشكران بُعد روانشناختى التزام ; Prasanna \& Swarnalatha, 2018; Leeds \& Nierle, 2014; Thakur, 2014 ; التزام (Bakker \& Demerouti, 2007; Salanova \& Schaufeli , 2008)، و بُعد رفتارى التزام Shuck \& Wollard, 2010; Ahmed et al., 2012; Ariani, 2013; Roof, 2015;) (Conway et al., 2016; Lyu, 2016; Holland et al., 2017 بالا هر كدام از يك يا جند بُعد به بررسى التزام كار كنان معيردازند. آنجه از ادبيات يثرهش استنباط

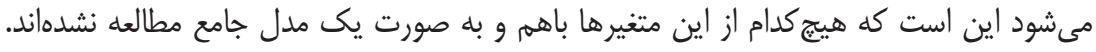

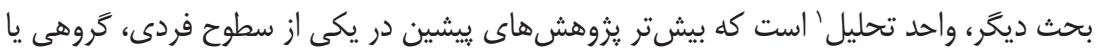

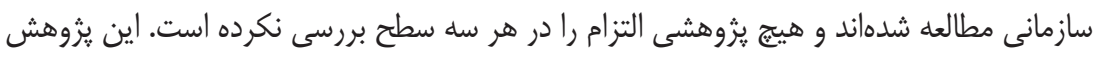
سعى دارد تا در قالب يك مدل، عوامل رفتارى تاثير كذار را در التزام كاركنان ارائه كند.

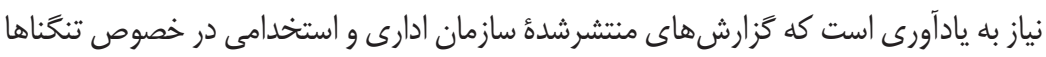

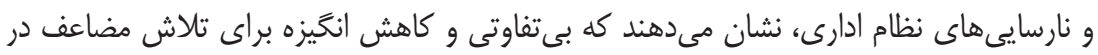

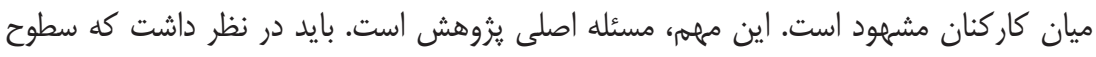

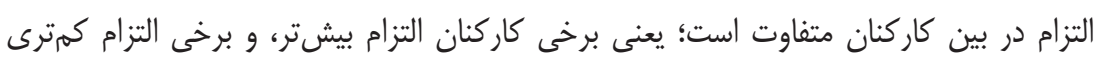

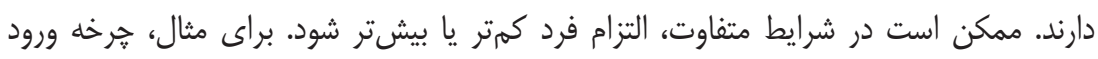

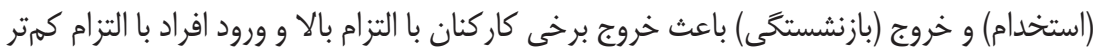

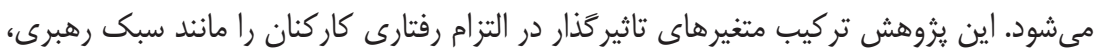

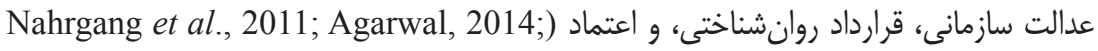
مد نظر قرار مىدهد كه در سه سطح فردى، (Tims et al., 2011; Karanges et al., 2015 كروهى، و سازمانى قرار دارند. از اين راه مىتوان به ارائه مدل جامع و اثربخش در راستاى ارتقاى

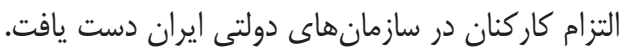




\section{مبانى نظرى و وِيشينة هُووهش}

\section{تعريف التزام}

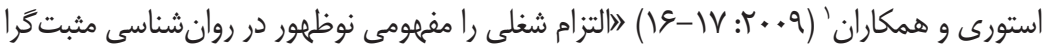
مى دانند كه بر توان و انرزى نيروى انسانى، كار كردن در حد مطلوب، و تجارب كارى مثبت تمركز

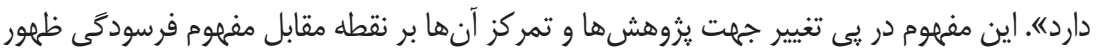

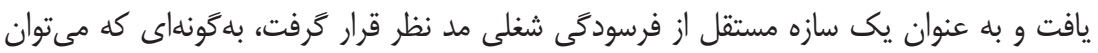

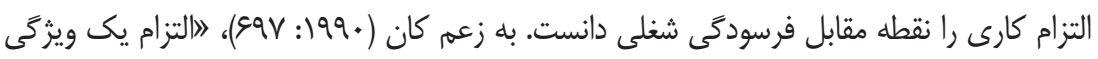
تعريف شده است كه كاركنان براى انعكاس وابستخى به مسئوليت كار از خود بروز مىدهند و بدين

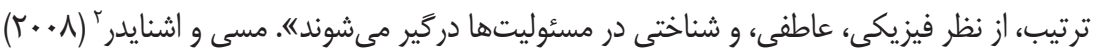

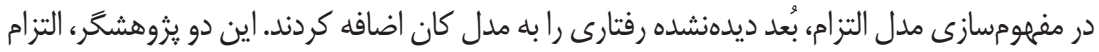

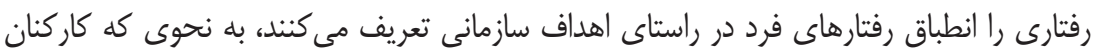
بلهور واقعى احساس ارزشمند بودن را در سازمان تجربه كنند. اين تجربه باعث ايجاد انرزى مثبت إنباف

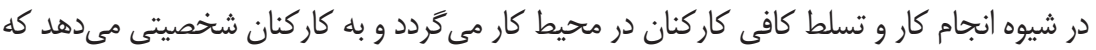

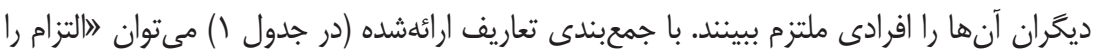

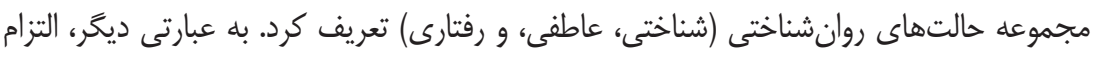

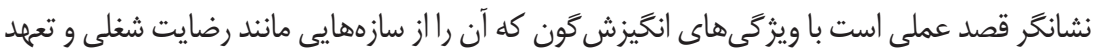

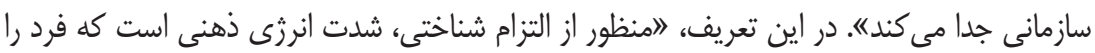

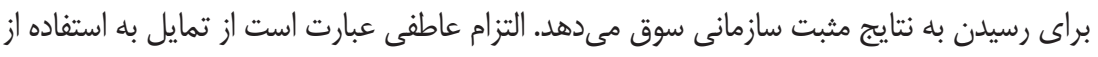

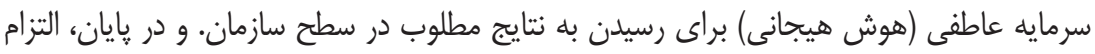

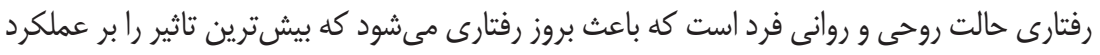
و نتايج مثبت سازمانى دارنده (Nimon et al., 2016: 3 (N).

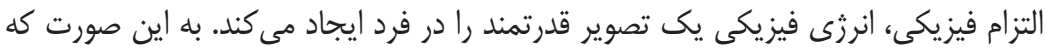

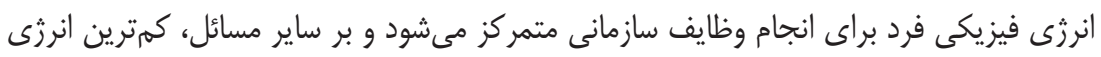
صرف مىشود. اين انرزى به صورت فزاينده باعث ايجاد فرصتهاى توسعه بيشتر و ايجاد ارزش فران در فرد و سازمان مىشود (Macey et al., 2009).

1. Storey et al

2. Macey \& Schneider 
جدول ا: تعريف التزام از ديدكاه انديشمندان علوم رفتارى

\begin{tabular}{|c|c|c|}
\hline تعريف & منبع & رديف \\
\hline 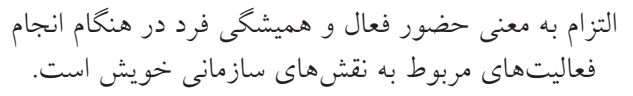 & He et al. (2014: 684) & 1 \\
\hline 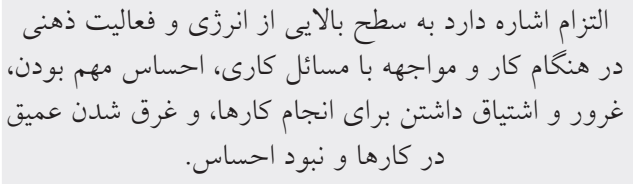 & Park \& Gursoy (2012: 1198) & r \\
\hline و التزام شغلى يكى منبع انرزى است كه باعث انخيزش بيشت باتر & Inceoglu \& Fleck (2010: 37) & r \\
\hline 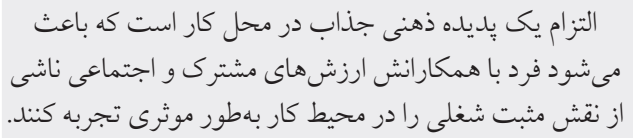 & Soane et al. (2012: 531) & q \\
\hline
\end{tabular}

\section{سنجش التزام كاركنان}

براى ارزيابى التزام كار كنان جندين ابزار وجود دارد. اما نياز است تا بر ابزارهايى متمركز شويم

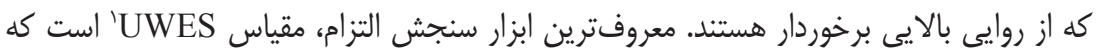

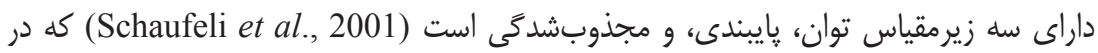

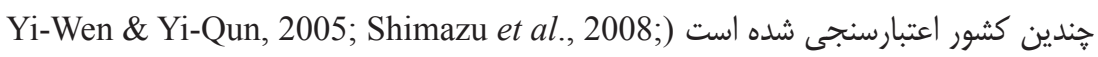
(Storm \& Rothmann, 2003; Schaufeli \& Bakker, 2003

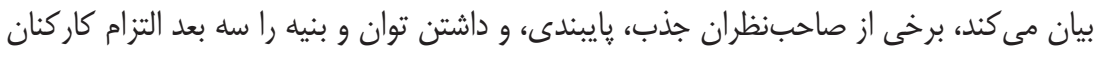

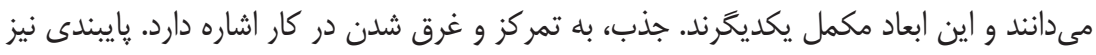

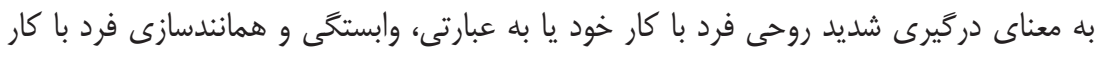

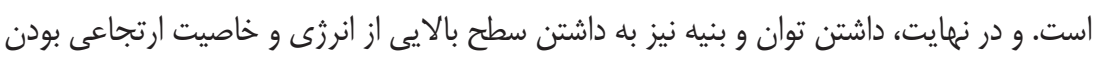

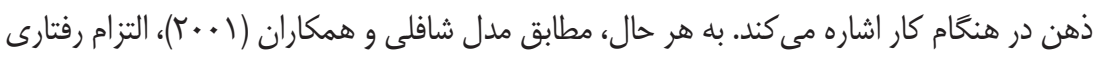

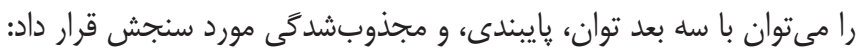

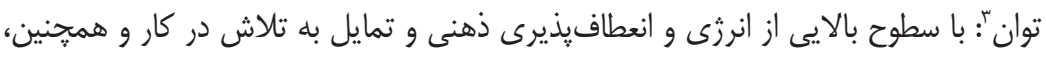

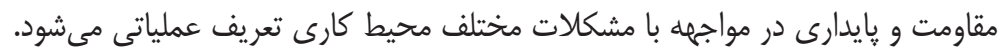

1. Utrecht Work Engagement Scale (UWES)

2. Reed

3. Vigor 
ֶايبندى': با نماگرهايى جُون معنادارى، شور و اشتياق در محيط كار، افتخار و غرور در انجام

خدمت وظيفه، و ايجاد جالش تعريف مى شود.

مجذوبشدگى 'ّ نشانگر وضعيتى است كه فرد بر انجام كار بهطور شايسته تمركز دارد؛ در

انجام كار خود غوطهور است، بلهورى كه زمان برايش بهسرعت سيرى مىشود و متوجه اطراف

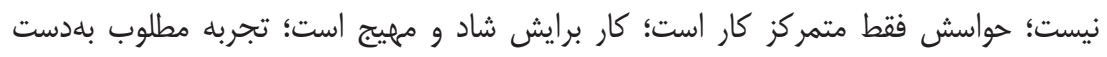
مى آورد؛ و از كارش لذت مىبرد.

\section{عوامل اثركذار در التزام كاركنان}

يزوهشهاى قابلتوجهى در خصوص شناسايى متغيرهاى تاثير گذار در التزام كاركنان صورت

گرفتهاند. از ديدگًاه رويلِ و همكاران (9 +. r) عوامل موثر در التزام كاركنان عبارتاند از: همترازى راهبرد، طبيعت زندگى حرفهاى، امنيت شغلى، اعتماد به رهبر ارشد، طبيعت شغل، ارتباط كارى با هول مدير ارشد، فرهنگ همكارى، يرداخت منصفانه، فرصتهاى توسعه، و بلرسميت شناختن كاركنان.

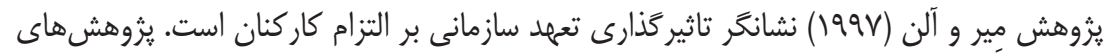
ديخرى نيز با هدف شناسايى عوامل موثر در ارتقاى التزام كاركنان صورت كرفته است كه نتايج

آنها در جدول (r) منعكس شده است.

جدول ז: عوامل تاثير كذار در التزام كار كنان

\begin{tabular}{|c|c|c|}
\hline عومل تاثير گذار & منبع & رديف \\
\hline تعهد سازمانى & $\begin{array}{l}\text { Meyer \& Allen (1997); } \\
\text { Purcell et al. (2003) }\end{array}$ & 1 \\
\hline 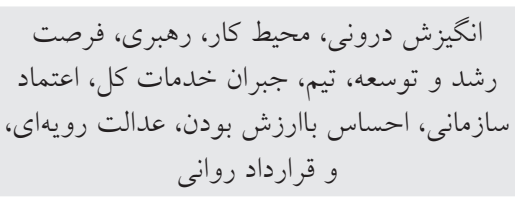 & $\begin{array}{l}\text { Robinson (2006); Anitha (2014); } \\
\text { Robinson et al. (2004) }\end{array}$ & r \\
\hline ارتباط با بالادستى، امنيت شغلى، و حمايت & May et al. (2004); Allen et al. (2008) & r \\
\hline شخصيت & $\begin{array}{l}\text { Wildermuth (2008); } \\
\text { Woods \& Sofat (2013) }\end{array}$ & r \\
\hline
\end{tabular}

1. Dedication

2. Absorption 
ادامه جدول rا: عوامل تاثير كذار در التزام كار كنان

\begin{tabular}{|c|c|c|}
\hline عومل تاثير گذار & منبع & رديف \\
\hline وضوح نقش، ارتباط، تعهد سازمانى، و جبران & $\begin{array}{l}\text { Mohapatra \& Sharma (2010); } \\
\text { De Villiers \& Stander (2011) }\end{array}$ & $\Delta$ \\
\hline تعصب مذهبى & $\begin{array}{l}\text { Mitroff \& Denton (1999); } \\
\quad \text { Abu Bakar (2013) }\end{array}$ & 9 \\
\hline عدالت رويهاى، عدالت توزيعى و عدالت تعلى شعلى املى، و اعتماد، & Saks (2006); Nair \& Salleh (2015) & V \\
\hline فرصت رشد و توسعه، منابع شغلى، منابع امنيت شعلى و محيط كارى & $\begin{array}{l}\text { Shuck \& Albornoz (2007); } \\
\text { Xanthopoulou et al. (2009) }\end{array}$ & $\wedge$ \\
\hline امنيت شغلى، بازخورد سازنده، استقلال، منابع & Bakker \& Demerouti (2008) & 9 \\
\hline 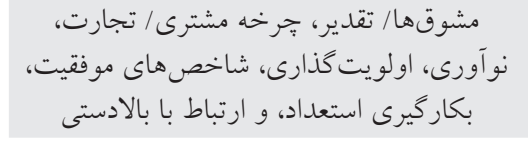 & Federman (2009) & 1. \\
\hline 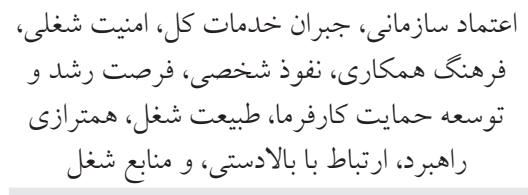 & $\begin{array}{l}\text { Ruyle et al. (2009); } \\
\text { Crawford et al. (2010) }\end{array}$ & 11 \\
\hline 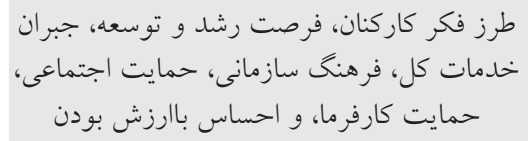 & Heslin (2010) & ir \\
\hline عوامل شخصيتى، فرهنگ همكارى، تعهل، & $\begin{array}{l}\text { Andrew \& Sofian (2011); } \\
\text { Keating \& Heslin (2015) }\end{array}$ & $\pi$ \\
\hline عدالت سازمانى و حمايت سازمانى & Ahmed et al. (2012) & 14 \\
\hline نقش تعديلگرى استقلال در روابط بين بازخورد & Menguc et al. (2013) & 10 \\
\hline نقش تعديل گرى اعتماد سازمانى در روابط بين & Agarwal (2014) & 19 \\
\hline 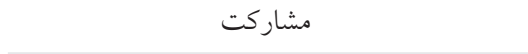 & Benn et al. (2015) & IV \\
\hline رهبرى & $\begin{array}{l}\text { Carter \& Baghurst (2014); } \\
\text { Breevaart et al. (2014) }\end{array}$ & 11 \\
\hline
\end{tabular}


با توجه به مبانى نظرى و ييشينأ يزوهش، \\ متغير كليدى تاثير گذار در سه سطح فردى، كروهى، و سازمانى شناسايى شدند. جهار متغير در سطح سازمانى بر متغير التزام رفتارى كاركنان

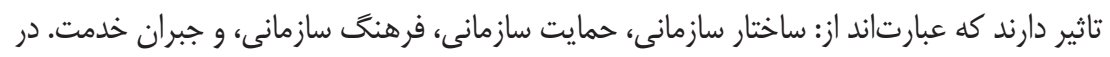

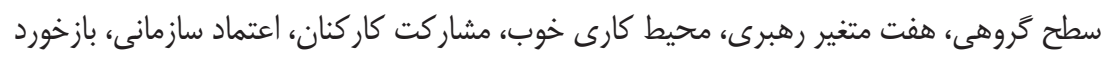

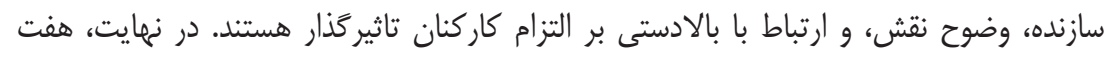

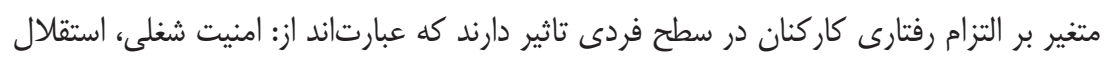

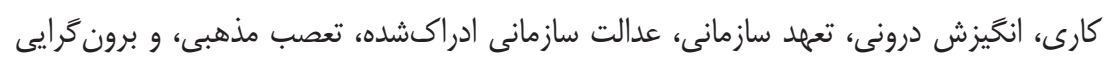

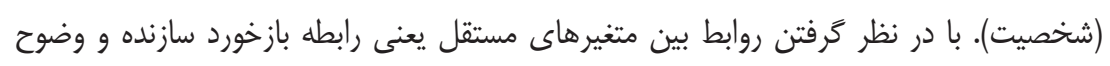

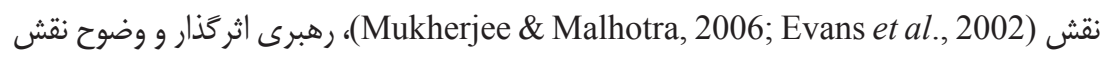

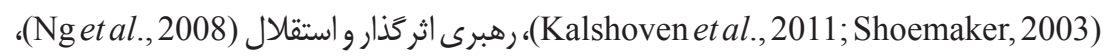

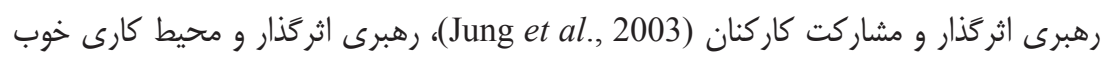

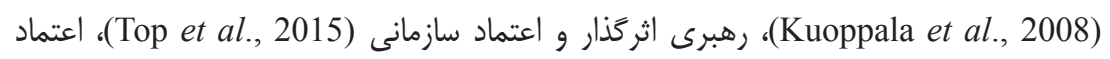

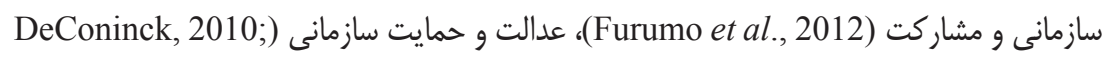

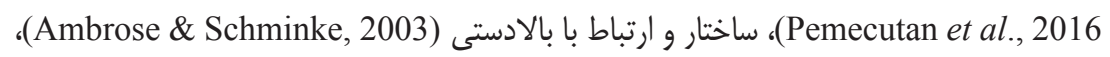

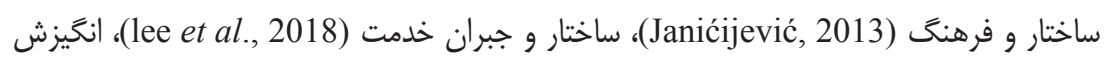

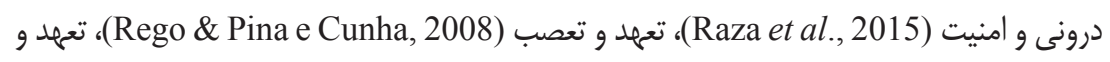

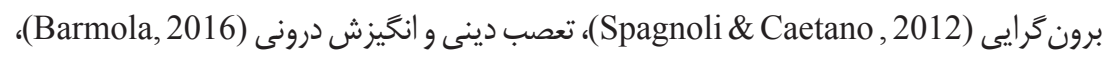

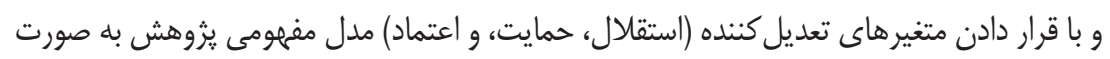
شكل (1) - مير بهدست آمد. 


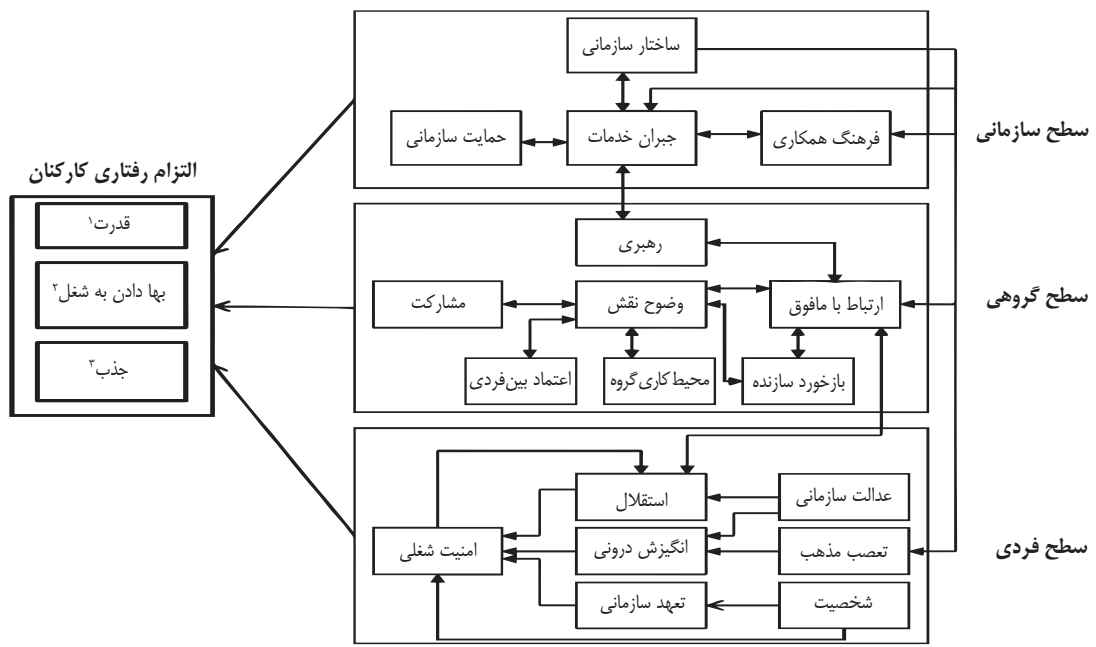

روش شناسى : روهش

راهبرد اين يزوهش، ييمايش است. در ضمن، اين يُوهش از نظر افق زمانى، تكىقطعى است. با توجه به اين كه واحد تحليل، سازمان است و يثوهشخران قصد دارند تا مدلى را براى التزام كاركنان در بخش دولتى ارائه دهند، پِ جامع جآ آمارى اين يثوهش شامل سازمان هاى دولتى ايران است كه VA سازمان برآورد شده است. مطابق با جدول مورگان، هو سازمان به عنوان نمونه به روش تصادفى نظاممند انتخاب شدند (نادرى و سيف نراقى، • وسا). در اين يثوهش، سنجههاى هر \ل متغير استفادهشده مبتنى بر ادبيات گردآورى شدند كه با توجه به نظرخواهى از استادان و

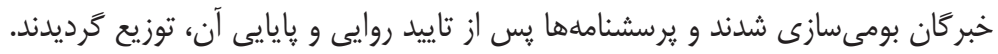

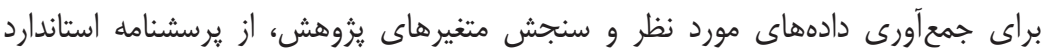
و بومىشده استفاده شده است. نماكرهاى مورد سنجش، ييش از آنكه در قالب يرسشنامه بـ

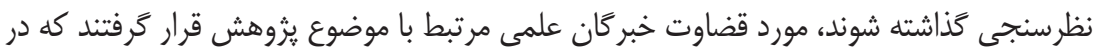
نهايت، از يرسشنامه مورد توافق به عنوان ابزار جمع آورى دادهها استفاده شد. يرسشنامهها، در هر

1. Vigor

2. Dedication

3. Absorption 
سازمان به صورت لينك الكترونيك ميان مديران و كارشناسان توزيع شدند و دادههاى سطح فردى

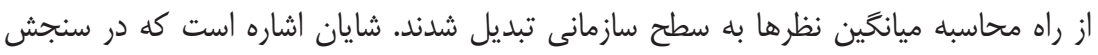

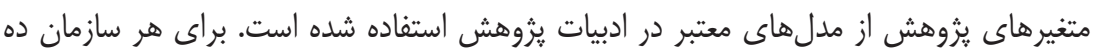

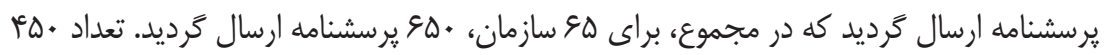

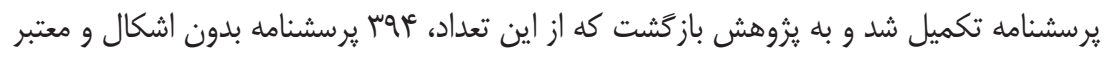

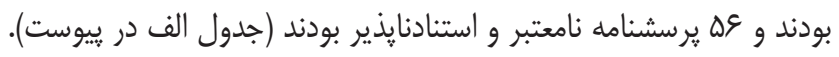
در اين يزوهش، براى تعيين روايى از نسبت روايى محتوايى لاوشه' (19VD) استفاده شده

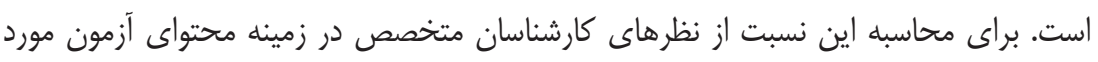

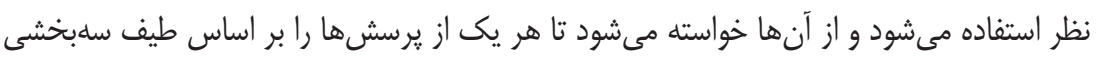

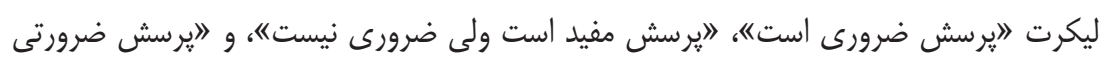

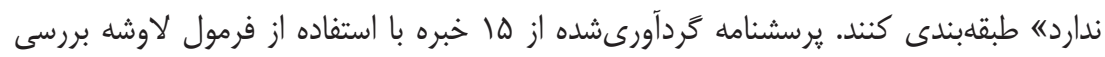

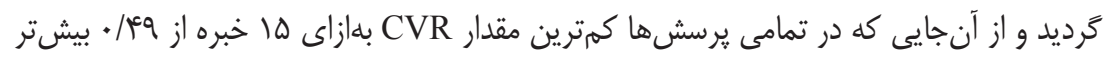

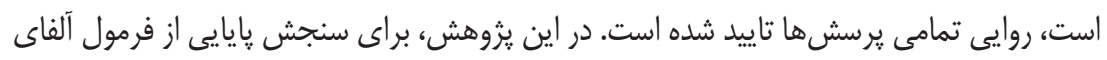

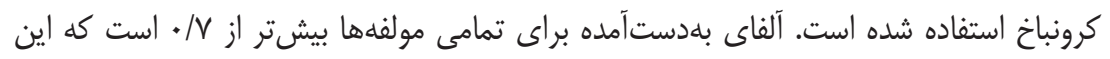
عدد، نشانخر پايايى مناسب يرسشنامه است.

\section{تعريف عملياتى متغير هاى بزوهش}

جبران خدمت" مفهوم كَستردهاى است كه فرايند طراحى نظامهاى حقوق و دستمزد، نظامهاى

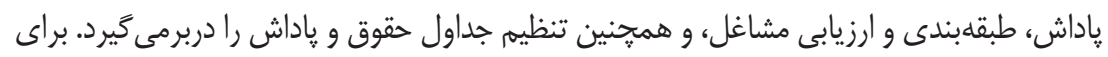

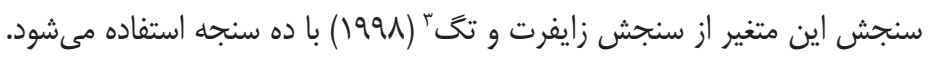

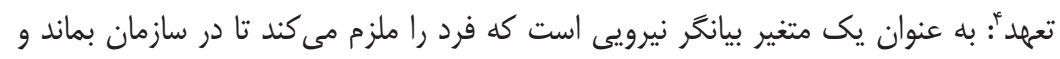

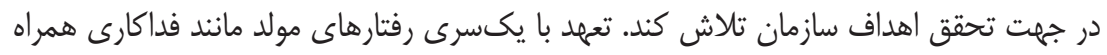

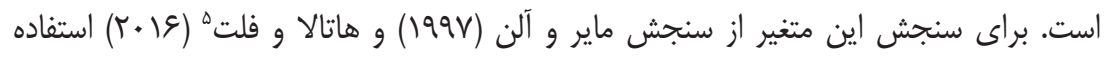

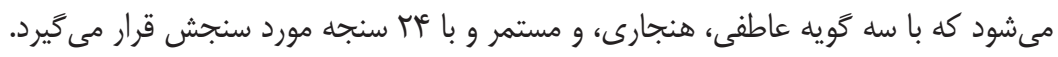

1. Lawshe

2. Compensation

3. Seifert \& Tegg

4. Commitment

5. Huhtala \& Feldt 
رهبرى': به عنوان يك متغير بيانكَ نيرويى است كه فرد را ملزم مى كند تا در سازمان بماند و در جهت تحقق اهداف سازمان تلاش كند و با يكسرى رفتارهاى مولد مانند فداكارى همراه است.

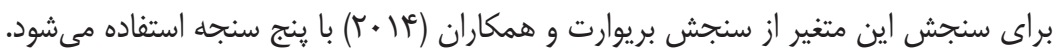

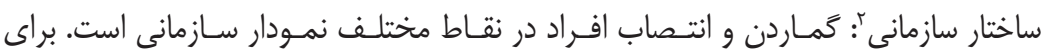

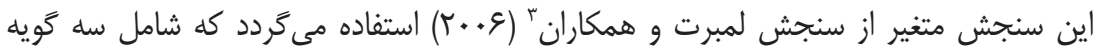
يبيجيدگى، تمركز، و رسميت با بآب سنجه است.

التزام كاركنان": كاركنان ملتزم كسانى هستند كه بهطور كامل مجذوب كار خود باشند،

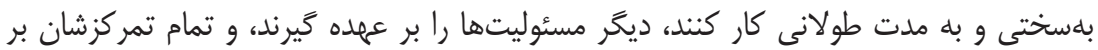

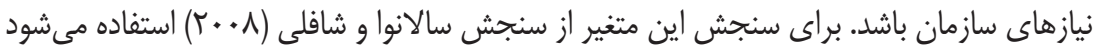

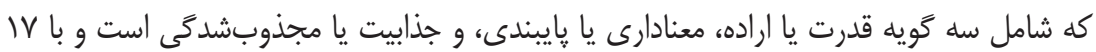
سنجه مورد سنجش قرار خواهد كرفت.

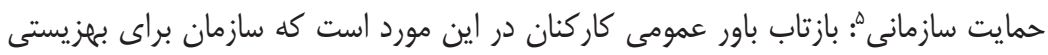

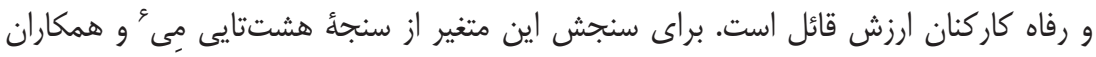

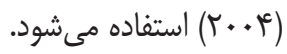

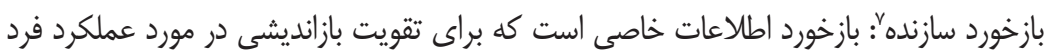

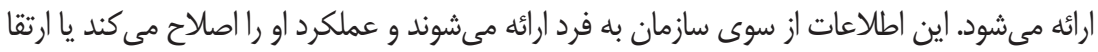

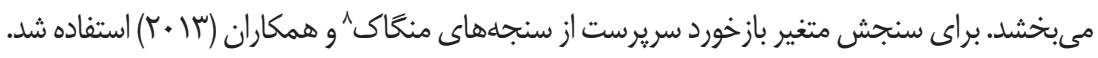

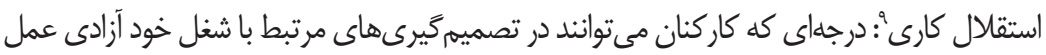

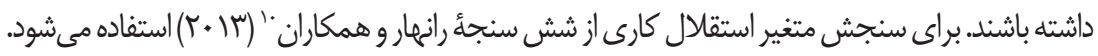

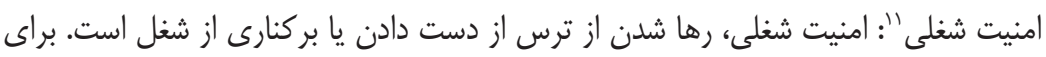

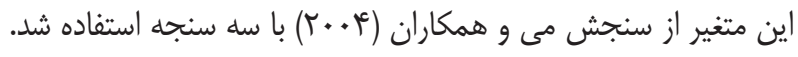

1. Leadership

2. Organizational Structure

3. Lambert et al.

4. Employee Engagement

5. Organizational Support

6. May

7. Constructive Feedback

8. Menguc

9. Work Autonomy

10. Runhaar et al

11. Job Security 
ارتباط با بالادستى': ارتباط با بالادستى فرايندى است كه مديران را براى كرفتن اطلاعات و

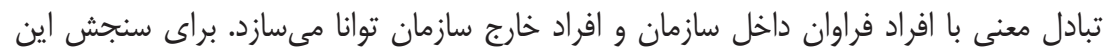

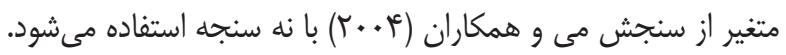

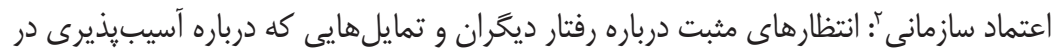

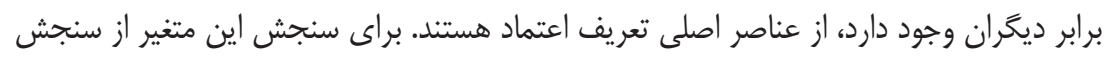

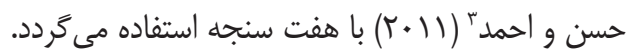

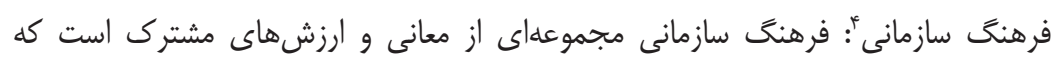

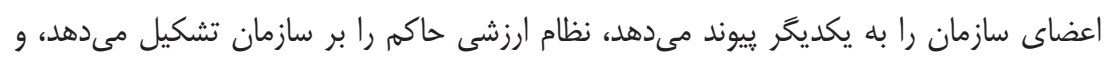

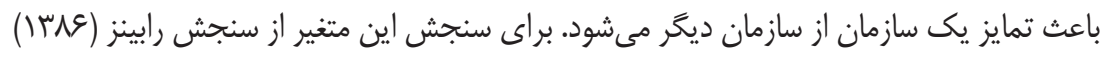

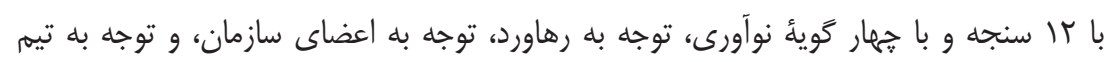

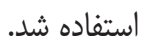

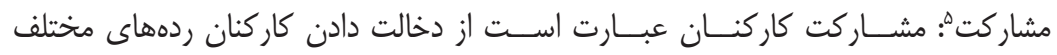

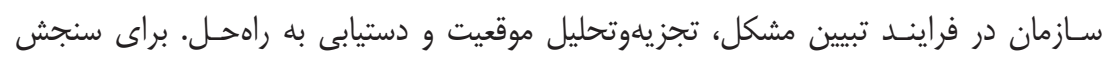

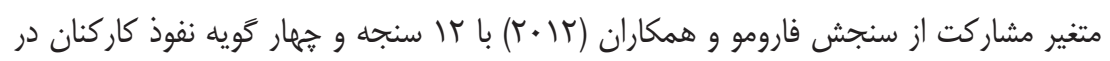

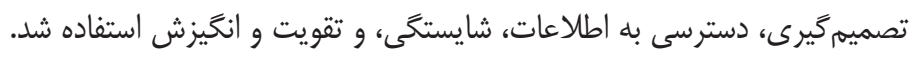

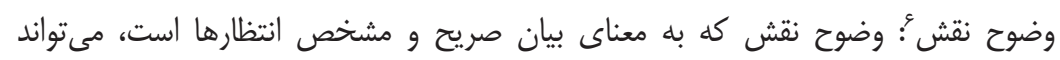

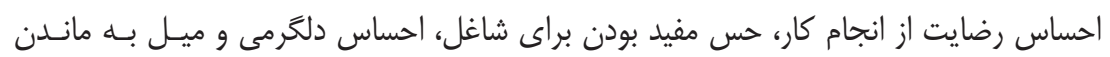

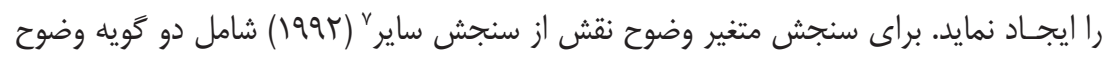
فرايند و وضوح هدف با شش سنجه استفاده شد.

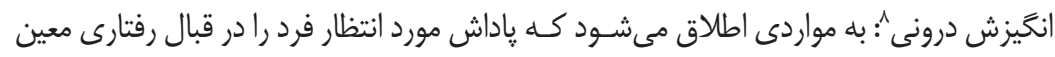

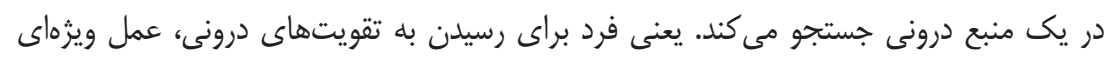

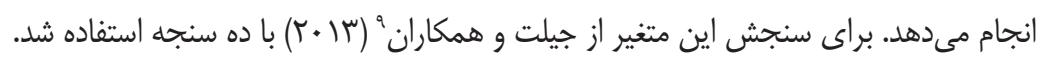

1. Communication with Superiors

2. Organizational Trust

3. Hassan \& Ahmed

4. Organizational Culture

5. Participation

6. Role Clarity

7. Sawyer

8. Internal Motivation

9. Gillet et al. 
تعصب دينى': به ايمان، شناخت، معرفت قلبى، اعتراف به زبان، و عمل به اعضا و جوارح اشاره

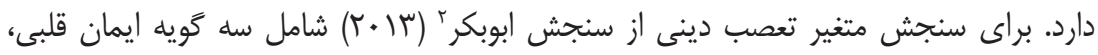
ايمان زبانى، و ايمان كردارى با يازده سنجه استفاده مى گَردد.

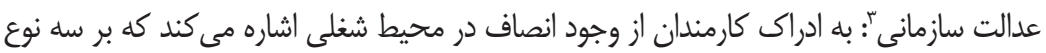

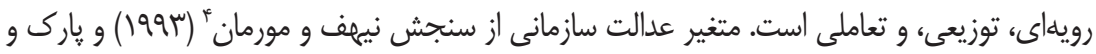

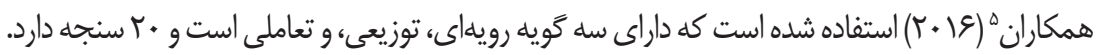

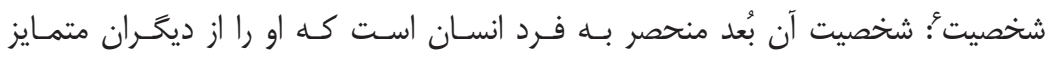

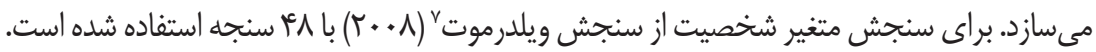

\section{كاهش خطاى تورش}

از بين بردن يا كاهش خطا نقش مهمى در بهبود كيفيت دادهاى جمع آورىشده دارد. در اين

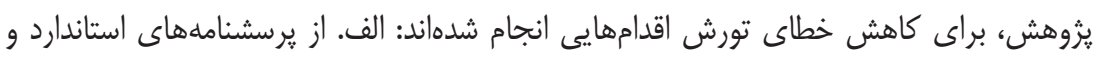

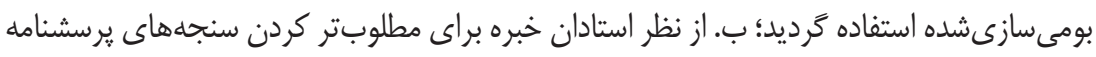
استفاده شد؛ و ج. يرسشنامههايى كه نقص داشتند و قابل اتكا نبودند، حذف كر ديدند.

\section{يافتهاى ثزوهش} آزمون دادهها متناسب با برسشهاى بزوهش به شرح زير ارائهيذير است.

\section{سطح التزام كار كنان}

براى پاسخ به اين يرسش يُروهش كه التزام كاركنان در خه سطحى است، فرضيههاى آمارى

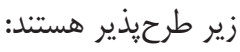

$\mathrm{H}_{0}: \mu \leq 3$

$H_{a}: \mu>3$

1. Religious Fanaticism

2. Abu Bakar

3. Organizational Justice

4. Niehoff \& Moorman

5. Park et al.

6. Personality

7. Wildermuth 
همانطور كه در جدول (بّ) مشاهده مىشود، سطح معنادارى مشاهدهشده براى ابعاد سه كَانه

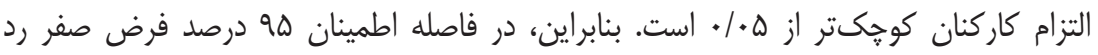

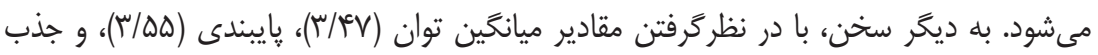
كه (ب/VI) ايران در سطح بلهنبت مطلوبى هستند.

جدول بّ: آمارهاى استنباطى ابعاد التزام كاركنان

\begin{tabular}{|c|c|c|c|c|c|c|}
\hline \multicolumn{6}{|c|}{ r ارزش آزمون=r } & \multirow{3}{*}{ ابعاد } \\
\hline \multicolumn{2}{|c|}{ فاصله اطمينان ه9 درصد } & & 1). & $1 . \bar{T}$ & T & \\
\hline كرانه پايين & كر انه بالا & & & & & \\
\hline - MTS & .1949 & $r / \mathcal{L V}$ & $\cdot / \cdots$ & 90 & $9 / \mu k$. & 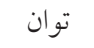 \\
\hline . AMt & $.19 \vee 9$ & $r / \Delta 0$ & $\cdot / \cdots$ & 90 & $9 / 1 \pi r$ & 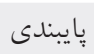 \\
\hline.$/ 91 \mathrm{r}$ & $\cdot / \vee 91$ & $r / v 1$ & $\bullet / \cdots$ & 90 & $10 / 419$ & جذب \\
\hline
\end{tabular}

در ضمن، التزام علمى كاركنان در سازمانهاى دولتى مورد مطالعه در نمودار تار عنكبوتى نيز مقايسه شده است. همانطور كه در نمودار (1) ديده مىشود، كاركنان مركز تحقيقات راه، مسكن، و شهرسازى با ميانگين (T/NT) داراى يايينترين التزام، و كاركنان وزارت فرهنَ و ارشاد

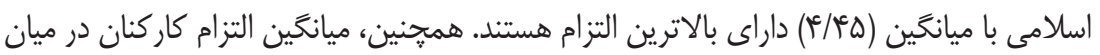
سازمانهاى مورد مطالعه r/DV است كه با در نظرگرفتن مقياس ڤنج درجهاى ليكرت، در سطح

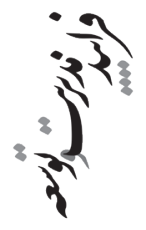
بالاى متوسط است. 


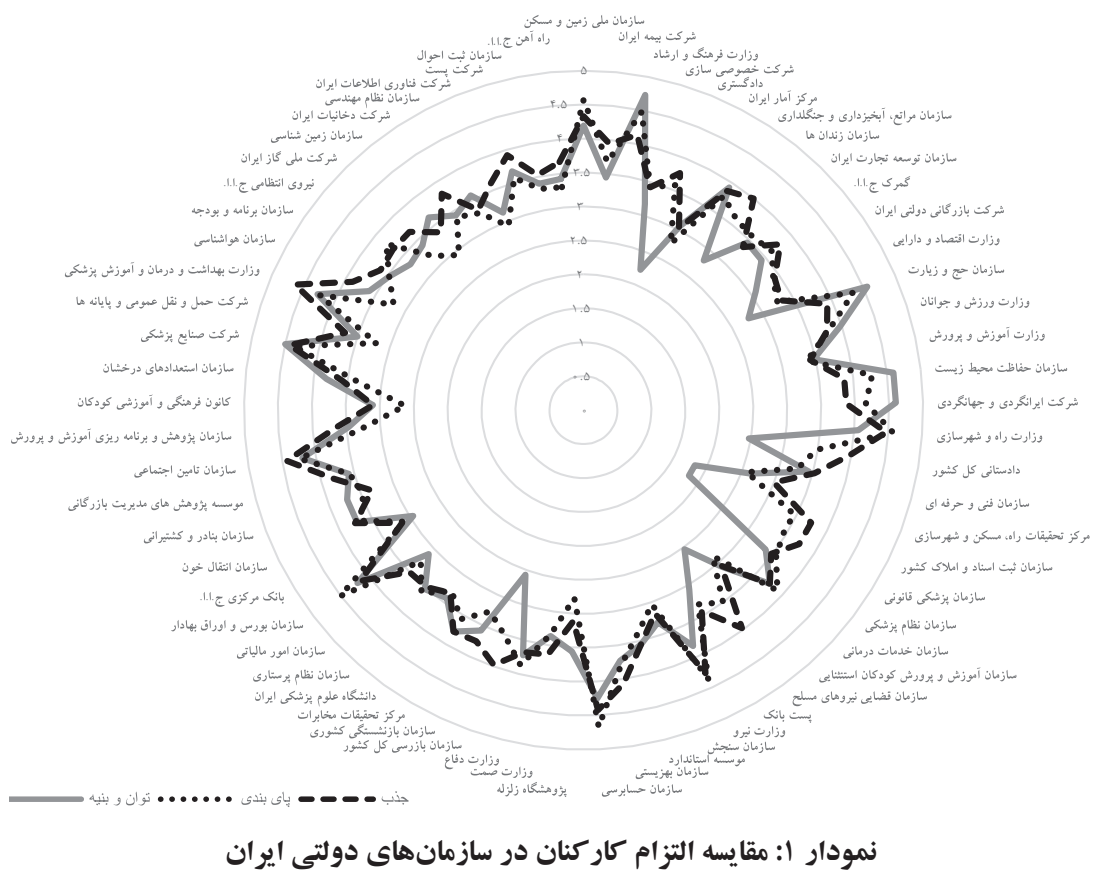

مدل معادلههاى ساختارى

با توجه به اين كه التزام عملى كار كنان دستخاههايى اجرايى در سطح بالاى متوسط است، براى

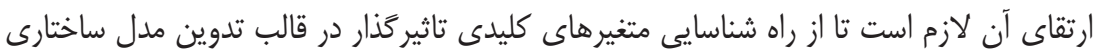

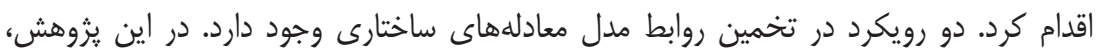

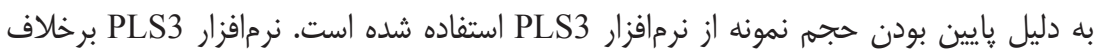
نرمافزارهاى LISREL و مبتنى بر كوواريانس نيست و واريانسمحور است؛ به همين دليل، تحليل اكتشافى و تحليل مسير را همزمان انجام مىدهد (Hair et al., 2016). نتايج تحليل در شكل (ז) منعكس شده است. 


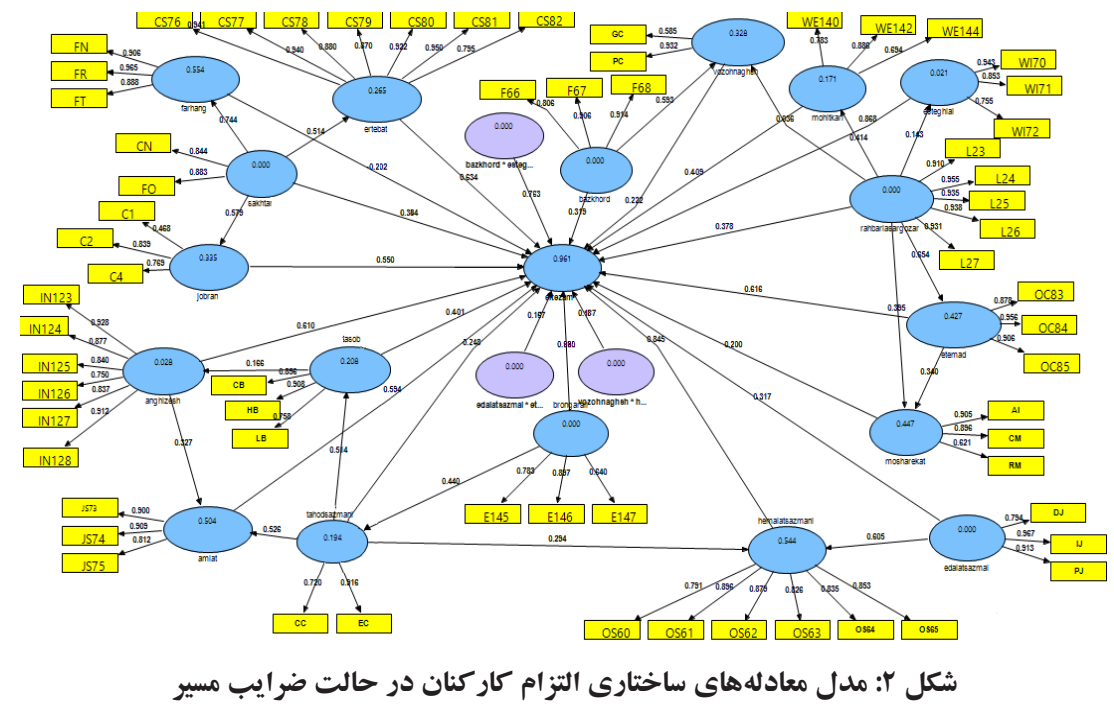

براى بررسى معنادارى ضر ايب مسير، از آماره t استفاده شده و نتايج آن در جدول (أ) منعس دما

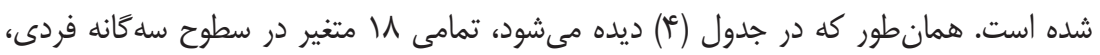

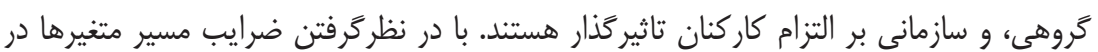

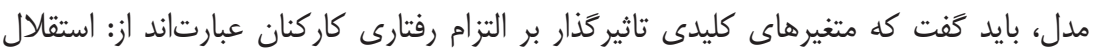

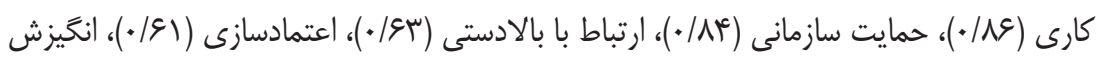

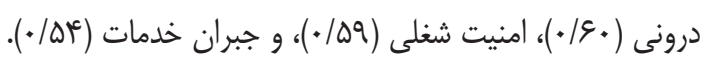

جدول †: بررسى معنادارى ضرايب مسير و آزمون روابط متغيرها

\begin{tabular}{|c|c|c|c|}
\hline نتيجه آزمون & ضرايب مسير & آماره t & روابط متغيرها \\
\hline تاييد & $\cdot / 094$ & $\mid \varphi / \mu v$. & |منيت ->> التزام \\
\hline تاييد & $\cdot$ MTG & $\Delta / Y \wedge 1$ & انخيزش ->>امنيت \\
\hline تاييد & $\cdot 19 \cdot 9$ & $9 / \mu Y \Lambda$ & انخيزش ->> التزام \\
\hline تاييد & $\cdot / \Lambda \Lambda$ & $r / l \cdot 1$ & بازخورد ->> التزام \\
\hline تاييد & $\cdot / 094$ & $V / T l$ & بازخورد ->>وضوح نقش \\
\hline تاييد & $\cdot / \Lambda \Lambda$ & Y/QIT & برونكرايى _> التزام \\
\hline تاييد نشد & $\cdot / 4 k$. & $1 / \cdot \wedge r q$ & برون كرايى _> تعهد سازمانى \\
\hline تاييد & $\cdot / \mu I V$ & $r / 1 r q$ & عدالت سازمانى _> التزام \\
\hline
\end{tabular}


ادامه جدول ثا: بررسى معنادارى ضر ايب مسير و آزمون روابط متغيرها

\begin{tabular}{|c|c|c|c|}
\hline نتيجه آزمون & ضرايب مسير & آماره t & روابط متغيرها \\
\hline تاييد & $\cdot 19 \cdot 4^{4}$ & r/DVY & عدالت سازمانى ->> حمايت سازمانى \\
\hline تاييد & . - (9MT & r/QVQ & ارتباط ->> التزام \\
\hline تاييد & $\cdot / \wedge \& V$ & $\Delta / \cdot \Delta V$ & استقلال شغلى _> التزام \\
\hline تاييد & .1919 & r/QVG & اعتماد سازمانى _> التزام \\
\hline تاييد & • & $r / 99$. & اعتماد سازمانى _> مشاركت \\
\hline تاييد & $\cdot / r \cdot 1$ & $1 / 994$ & فرهنگ همكارى -> التزام \\
\hline تاييد & $\cdot / N F D$ & $r / \cdot v \cdot$ & حمايت سازمانى _> التزام \\
\hline تاييد & $\cdot / 049$ & $1 \mathrm{~T} / 99 \mathrm{~T}$ & جبران خدمت ->> التزام \\
\hline تاييد & $\cdot / 4 \cdot \wedge$ & $r / 9 \Lambda$ & محيط كارى -> التزام \\
\hline تاييد & $\cdot / r \cdots$ & $r / q r \mu$ & مشاركت كاركنان ->> التزام \\
\hline تاييد & $\cdot / \mu V V$ & $r / 91 Y$ & رهبرى اثر كذار ->> التزام \\
\hline تاييد نشد &.$/ 1 k 4$ & l/lkr & رهبرى اثركذار _> استقلال \\
\hline تاييد & . $190 \mathrm{r}$ & $11 / 094$ & رهبرى اثرخذار -> اعتماد \\
\hline تاييد &.$/ 4 i r$ & $\Delta / \Delta Q Y$ & رهبرى اثر گذار _>> محيط كارى \\
\hline تاييد & .1919 & $9 / 194$ & رهبرى اثر گذار ->> مشاركت \\
\hline تاييد نشد & $\cdot / \cdot r \Delta$ & $\cdot / T T V$ & رهبرى اثر گذار ->> وضوح نقش \\
\hline تاييد & $\cdot / r \Lambda \uparrow$ & T/19Y & ساختار ->> التزام \\
\hline تاييد &.$/ 014$ & $9 / \pi 99$ & ساختار ->> ارتباط با بالادستى \\
\hline تاييد & - Mat & $\mathrm{IV} / \mathrm{A}$ & ساختار -> فرهنگ همكارى \\
\hline تاييد & $\cdot / \Delta V \wedge$ & $9 / r \cdot 4$ & ساختار ->> جبران خدمت \\
\hline تاييد & $\cdot / D T Q$ & $r / \Lambda \cdot r$ & تعهد سازمانى -> امنيت شغلى \\
\hline تاييد & $\cdot / T Y A$ & MANOr & تعهد سازمانى -> التزام \\
\hline تاييد & $\cdot / r q 4$ & $Y / V Q Y$ & تعهد سازمانى ->>حمايت سازمانى \\
\hline تاييد نشد & $\cdot / 014$ & $1 / 91 Y$ & تعهد سازمانى -> تعصب دينى \\
\hline تاييد نشد & .1199 & $\cdot / 9 \vee \wedge$ & تعصب دينى ->> انخيزش درونى \\
\hline تاييد & $\cdot / 4 \cdots$ & $T / \cdot Y Q$ & تعصب دينى -> التزام \\
\hline تاييد & $\cdot$ / TYT & r/VVG & وضوح نقش -> التزام \\
\hline تاييد & - /VGr & $1 / 9 V$ & بازخورد × استقلال _> التزام \\
\hline تاييد &.$/ 199$ & $r / T \cdot r$ & عدالت × اعتماد ->> التزام \\
\hline تاييد &.$/ 119$ & r/4ar & وضوح نقش × حمايت -> التزام \\
\hline
\end{tabular}


در ضمن، يافتهاى يُوهش نشان مىدهند كه دريافت بازخورد، عدالت سازمانى، و وضوح

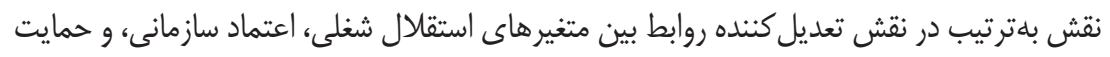
سازمانى با التزام رفتارى كار كنان ظاهر مى شعوند.

\section{ارزشيابى مدل ساختارى}

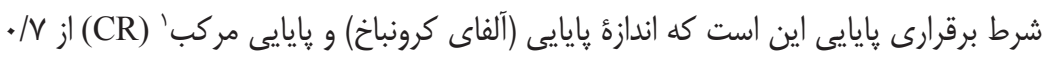

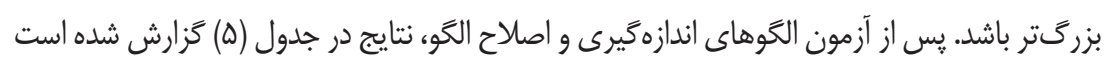

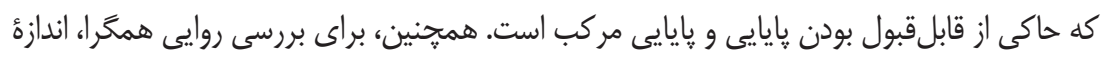
متوسط واريانس استخراجشده (AVE) بايد از ه/ • بزركتر باشد (Fornell \& Larcker, 1981). روايى تشخيصى (روايى واگرا) سازهها تاييد شده است.

جدول ه: ضرايب تعيين متغيرهاى وابسته در مدل ساختارى

\begin{tabular}{|c|c|c|c|c|}
\hline$\left(\mathbf{R}^{2}\right)$ & ضريب تعيين & متغير وابسته & ضريب تعيين (R') & متغير وابسته \\
\hline & $\cdot / D F Y$ & حمايت سازمانى & $\cdot / 0 \cdot r$ & امنيت شغلى \\
\hline & ס ס & جبر ان خدمت & $\cdot / \cdot T V$ & انخيزش درونى \\
\hline &.$/ I V I$ & محيط كارى & .199. & التزام رفتارى كار كنان \\
\hline & . /4ks & مشاركت كاركنان & $\cdot$. TSY & ارتباط با بالادستى \\
\hline &.$/ 194$ & تعهد سازمانى &.$/ \cdot r$. & استقلال كارى \\
\hline & $\cdot / r \cdot V$ & تعصب دينى & - MYT & اعتماد سازمانى \\
\hline & . MTV & وضوح نقش & . $/ 0 Q R$ & فرهنخ همكارى \\
\hline
\end{tabular}

\section{بحث و نتيجه كيرى}

امروزه روابط بين كاركنان و مديران رو به زوال است. يزوهشها نشان مىدهند كه درصد

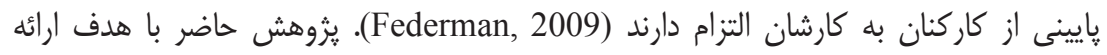

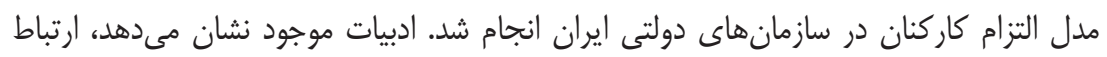

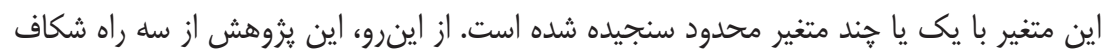

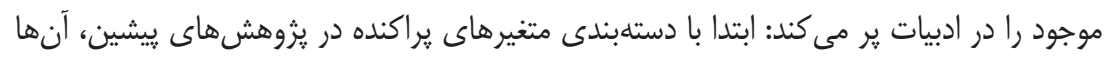

1. Construct Reliability

2. Average Variance Extracted 
را به سه دسته فردى، گروهى، و سازمانى طبقهبندى مى كند؛ سيس در هر سطح يك متغير به

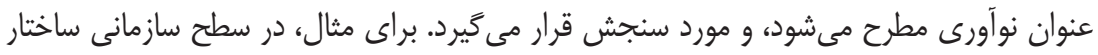

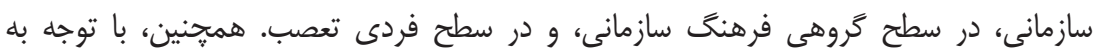

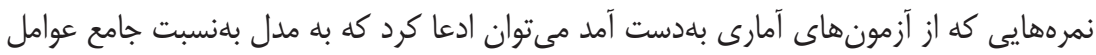

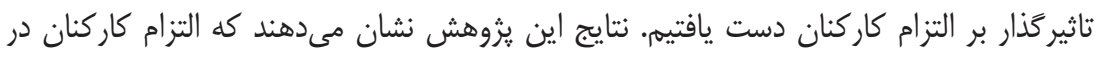
سازمان مورد مطالعه در سطح متوسط است. بنابراين، انجام تمهيدهاى لازم براى ارتقاى التزام

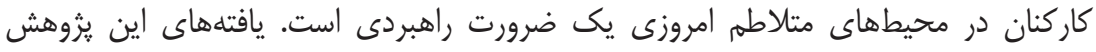

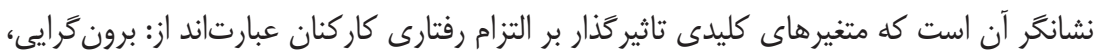

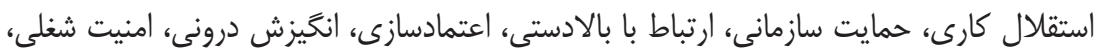

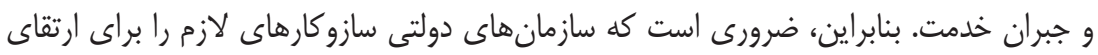

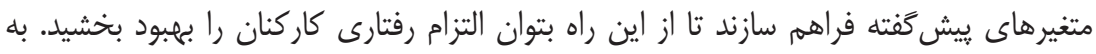

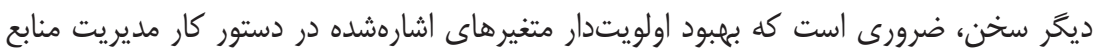
انسانى سازمانهاى دولتى قرار كيرد.

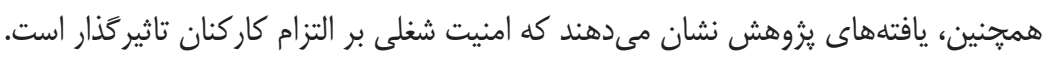

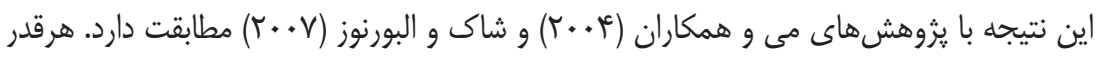

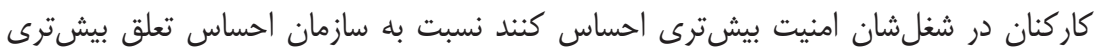

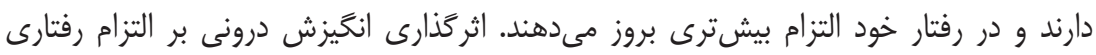

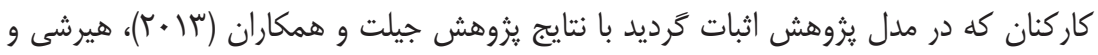

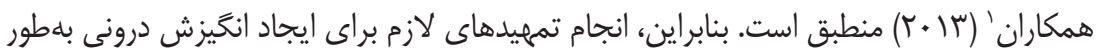

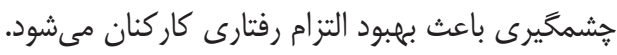

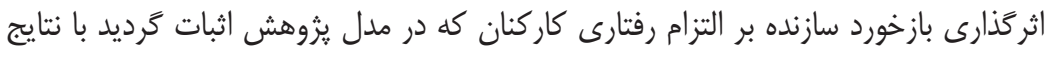

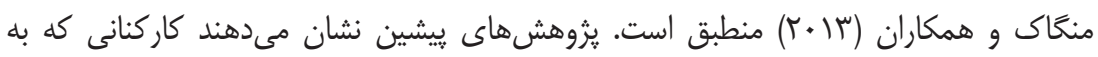

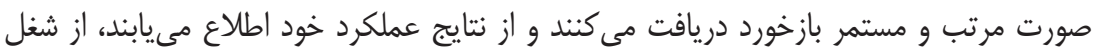

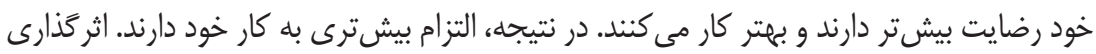
شخصيت (برون

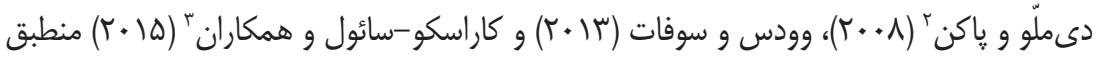

1. Hirschi et al

2. De Mello e Souza Wildermuth \& Pauken

3. Carasco-Saul et al 
است. نتايج يزوهش دىملّو و پاكن (1 + +r) به صورت خاص نشان مىدهد كه افراد با شخصيت برون

$$
\text { كارى دارند. }
$$

اثركذارى عدالت سازمانى بر التزام رفتارى كاركنان كه در مدل ثروهش اثبات گرديد با نتايج

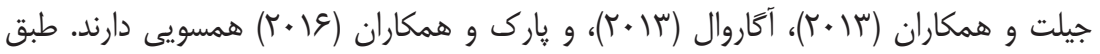
نتايج يزوهش، هر اندازه سازمانها در فرايندهايى مانند انتصاب، انتقال، جرخش شغلى، يرداخت

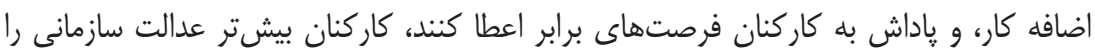
تجربه و درك خواهند كرد و تحت تاثير اين تجربه، عملكرد و التزام بيشترى ارائه خواهند داد. اثرگذارى ارتباط با بالادستى بر التزام رفتارى كاركنان با نتايح مى و همكاران (ع +. (r)، موهاياترا

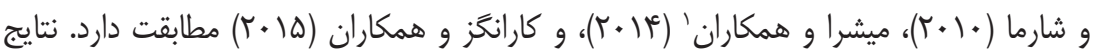
اين يزوهش و ديخر يزوهشها نشان مىدهند كه هرجقدر كاركنان بتوانند راحتتر با بالادستى

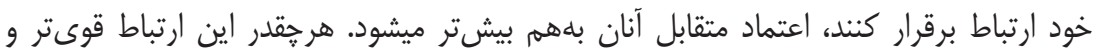
مستحكمتر باشد، التزام رفتارى كاركنان بالاتر مىرود.

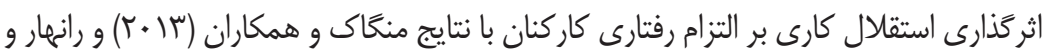

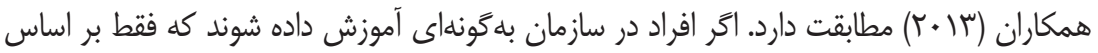
دستورالعملهاو قوانين خشك عمل كنند، بهتدريج به كاركنانى كسل، بـى حوصله، و فاقد انخَيزه تبديل

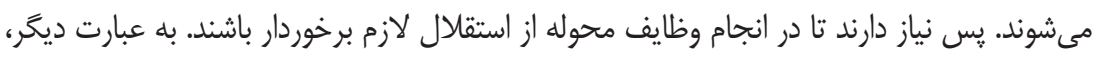
هرجقار بتوان استقلال كارى راد در كاركنان بالا برد، همراستا با آن التزامشان نيز بالاتر خواهد رفت.

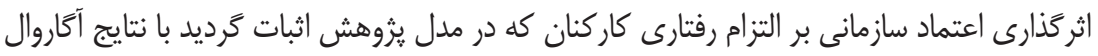

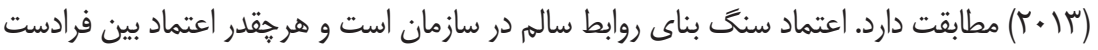
و زيردست يا افرادى كه باهم در يك سطح قرار دارند بالاتر باشد، بهرهورى و عملكرد سازمان ارتقا مىيابد. اعتماد بينفردى، رفتار افراد را در جهت بالاى رفتار التزام تقويت مى كند. اثرگذارى فرهنگ همكارى بر التزام رفتارى كاركنان كه در مدل يثوهش اثبات گرديد با

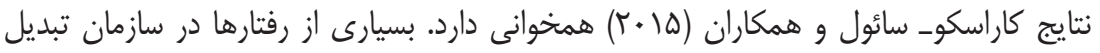
به ارزش و هنجار مىشوند و بهتدريج به صورت عادتى در سازمان جريان مىيابند مانند برخى از آيينها و مراسمهايى كه در سازمان بلوجود مى آيد و با تغيير افراد سازمان تغيير نمى كند و به صورت يك سنت يا اعتقاد خواهد ماند. يّ طبق نتايج اين يُوهش، هرجقدر فرهنَ سازمان به 
طرف همكارى و مشاركت سوق داده شود، باعث افزايش سطح التزام رفتارى در كاركنان خواهد

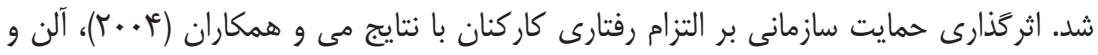

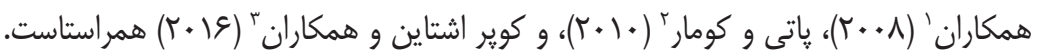

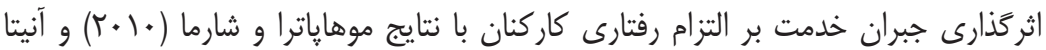

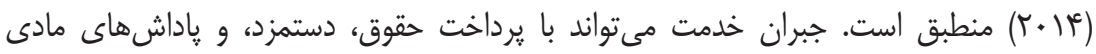

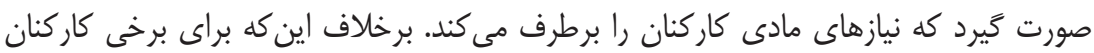

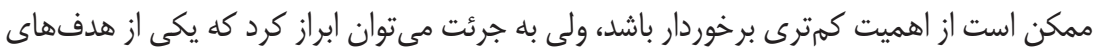

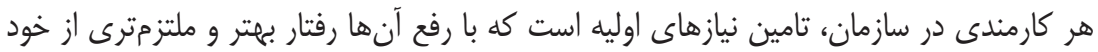

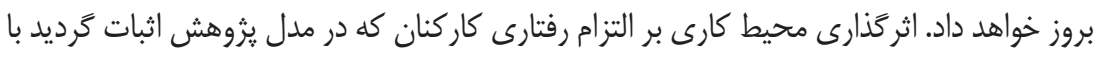

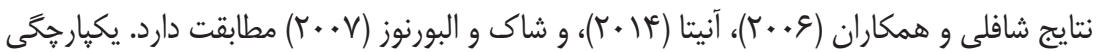

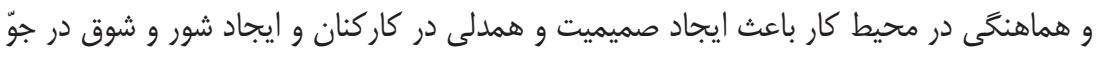

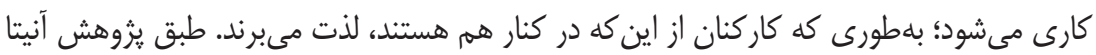

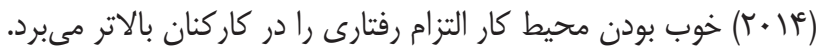

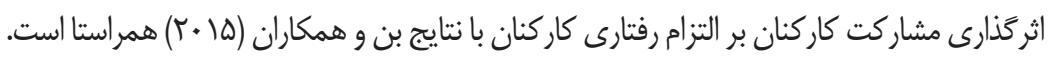
به عبارت ديخر، هرجقدر كاركنان توانايى مشاركت لازم را در تيههاى كارى داشته باشند و سازمان از ازتان افكار و انديشه آنان براى انجام بهتر وظايف محوله بهره ببرد، التزام رفتارى كار كنان ارتقامى يابدان.

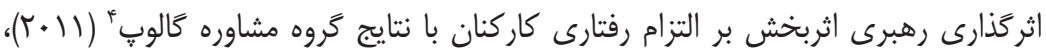

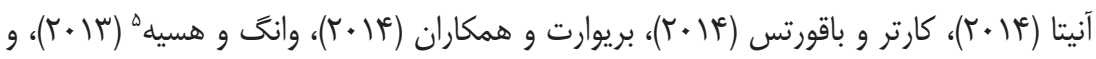

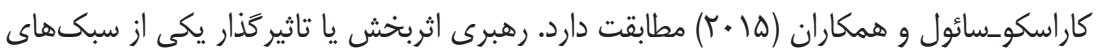

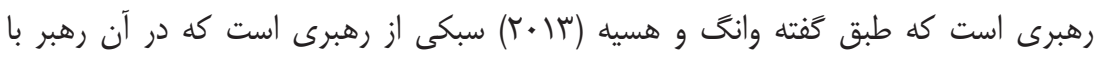

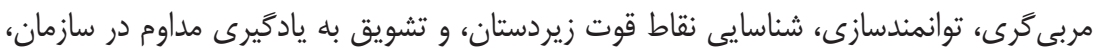

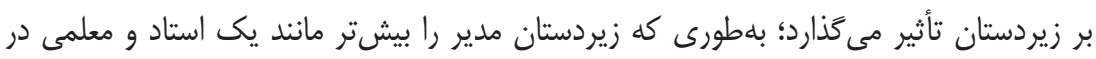

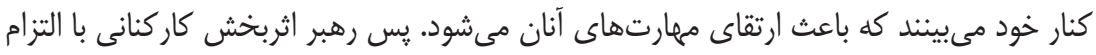
رفتارى بالا در سازمان تربيت مى كند.

1. Allen et al

2. Pati \& Kumar

3. Cooper Stein et al

4. Gallup

5. Wang \& Hsieh 


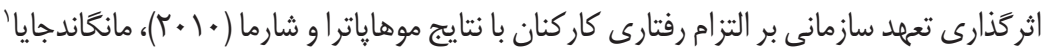

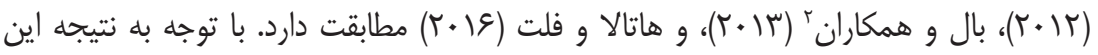
يزروهش مشاهده كَرديد كه افرادى كه تعهد سازمانى و شغلى بالايى دارند، افراد ملتزمترى هستند؛ زيرا تعهل مىتواند يك زيربنايى براى جذابيت، هايبندى به شغل، و توان (اراده) باشد.

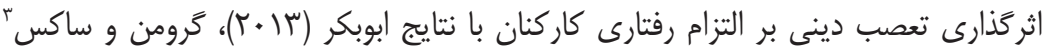

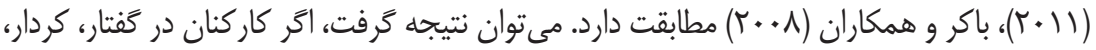
و رفتار خود صداقت داشته باشند و بر اساس آموزههاى دينى كه بلهدرستى و صداقت در كار تاكيد

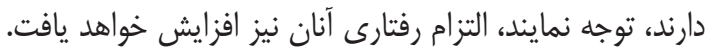

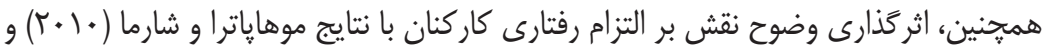

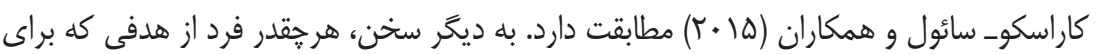
وظايفش در نظر كَرفته شده و فرايندهايى كه براى انجام موفقيتآميز آن وجود دارد، مطلع و آكاه باشد، از انجام كار خود لذت بيشترى مىبرد و باعث افزايش شفافيت نقشها در سازمان مى نشود و التزام رفتارى كار كنان را بالا مىبرد. در اين ثروهش مشخص شد كه برونَّرايى بر التزام كار كنان تاثير ندارد. اين يافته با يافتههاى

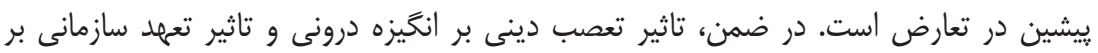

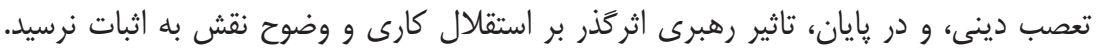

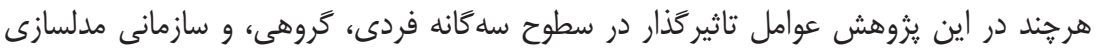
شدند، اما براى رسيدن به مدل بومى جامع ضرورى است كه اين يزوهش در سازمانهاى بخش

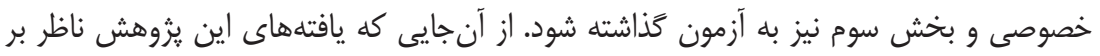
سازمانهاى دولتى ايران است، در خصوص تعميم يافتههاى آن به بخش دولتى ديخر كشورها

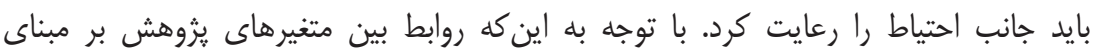
واريانس مدلسازى شدهاند، نبايد محدوديت اين روش را در مقايسه با مدلسازى ساختارى مبتنى بر

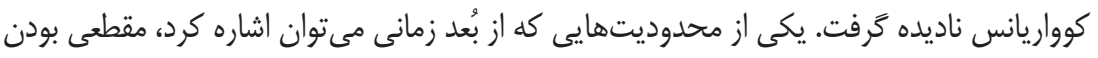

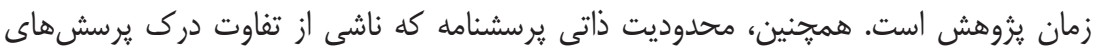
مطرحشده است، نبايد ناديده كرفت.

1. Mangundjaya

2. Bal et al.

3. Gruman \& Saks 


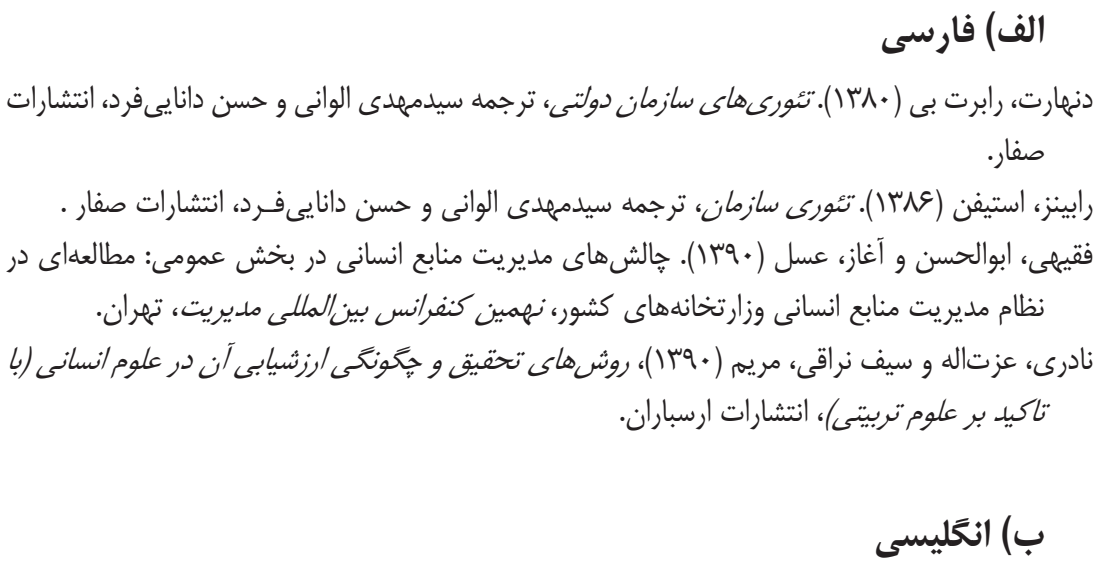

A. Agarwal, U. (2014). Linking Justice, Trust and Innovative Work Behaviour to Work Engagement. Personnel Review, 43(1), 41-73.

Abu Bakar, R. (2013). Understanding Factors Influencing Employee Engagement: A Study of the Financial Sector in Malaysia. (A Thesis Submitted in Fulfilment of the Requirements for the Degree of Doctor of Philosophy), University of Malaya.

Ahmed, N., Rasheed, A., \& Jehanzeb, K. (2012). An Exploration of Predictors of Organizational Citizenship Behaviour and its Significant Link to Employee Engagement. International Journal of Business, Humanities and Technology, 2(4), 99-106.

Allen, M. W., Armstrong, D. J., Reid, M. F., \& Riemenschneider, C. K. (2008). Factors Impacting the Perceived Organizational Support of IT Employees. Information \& Management, 45(8), 556-563.

Ambrose, M. L., \& Schminke, M. (2003). Organization Structure as a Moderator of the Relationship between Procedural Justice, Interactional Justice, Perceived Organizational Support, and Supervisory Trust. Journal of Applied Psychology, 88(2), 295-305.

Andrew, O. C., \& Sofian, S. (2011). Engaging People who Drive Execution and Organizational Performance. American Journal of Economics and Business Administration, 3(3), 569-575.

Anitha, J. (2014). Determinants of Employee Engagement and their Impact on Employee Performance. International Journal of Productivity, 63(3), 308.

Ariani, D. W. (2013). The Relationship between Employee Engagement, Organizational Citizenship Behavior, and Counterproductive Work Behavior. International Journal of Business Administration, 4(2), 46-56.

Bakker, A. B., \& Demerouti, E. (2007). The Job Demands-Resources Model: State of the Art. Journal of Managerial Psychology, 22(3), 309-328.

Bakker, A. B., \& Demerouti, E. (2008). Towards a Model of Work Engagement. Career Development International, 13(3), 209-223.

Bakker, A. B., Schaufeli, W. B., Leiter, M. P., \& Taris, T. W. (2008). Work Engagement: 
An Emerging Concept in Occupational Health Psychology. Work \& Stress, 22(3), 187-200.

Bal, P. M., Kooij, D. T., \& De Jong, S. B. (2013). How Do Developmental and Accommodative HRM Enhance Employee Engagement and Commitment? The Role of Psychological Contract and SOC Strategies. Journal of Management Studies, 50(4), 545-572.

Barmola, K. C. (2016). Spirituality and Motivation of College Students. The International Journal of Indian Psychology, 3(2), 84-88.

Benn, S., Teo, S. T., \& Martin, A. (2015). Employee Participation and Engagement in Working for the Environment. Personnel Review, 44(4), 492-510.

Breevaart, K., Bakker, A., Hetland, J., Demerouti, E., Olsen, O. K., \& Espevik, R. (2014). Daily Transactional and Transformational Leadership and Daily Employee Engagement. Journal of Occupational Organizational Psychology, 87(1), 138-157.

Carasco-Saul, M., Kim, W., \& Kim, T. (2015). Leadership and Employee Engagement: Proposing Research Agendas through a Review of Literature. Human Resource Development Review, 14(1), 38-63.

Carter, D., \& Baghurst, T. (2014). The Influence of Servant Leadership on Restaurant Employee Engagement. Journal of Business Ethics, 124(3), 453-464.

Conway, E., Fu, N., Monks, K., Alfes, K., \& Bailey, C. (2016). Demands or Resources? The Relationship between HR Practices, Employee Engagement, and Emotional Exhaustion within a Hybrid Model of Employment Relations. Human Resource Management, 55(5), 901-917.

Cooper Stein, K., Kintz, T., \& Miness, A. (2016). Reflectiveness, Adaptivity, and Support: How Teacher Agency Promotes Student Engagement. American Journal of Education, 123(1), 109-136.

Crawford, E. R., LePine, J. A., \& Rich, B. L. (2010). Linking Job Demands and Resources to Employee Engagement and Burnout: A Theoretical Extension and Meta-Analytic Test. Journal of Applied Psychology, 95(5), 834.

De Mello e Souza Wildermuth, C., \& Pauken, P. D. (2008). A Perfect Match: Decoding Employee Engagement-Part I: Engaging Cultures and Leaders. Industrial and Commercial Training, 40(3), 122-128.

De Villiers, J. R., \& Stander, M. W. (2011). Psychological Empowerment, Work Engagement and Turnover Intention: The Role of Leader Relations and Role Clarity in a Financial Institution. Journal of Psychology in Africa, 21(3), 405-412.

De Coninck, J. B. (2010). The Effect of Organizational Justice, Perceived Organizational Support, and Perceived Supervisor Support on Marketing Employees' Level of Trust. Journal of Business Research, 63(12), 1349-1355.

Evans, K. R., Schlacter, J. L., Schultz, R. J., Gremler, D. D., Pass, M., \& Wolfe, W. G. (2002). Salesperson and Sales Manager Perceptions of Salesperson Job Characteristics and Job Outcomes: A Perceptual Congruence Approach. Journal of Marketing Theory Practice, 10(4), 30-44.

Federman, B. (2009). Employee Engagement: A Roadmap for Creating Profits, Optimizing Performance, and Increasing Loyalty: John Wiley \& Sons.

Fornell, C., \& Larcker, D. F. (1981). Evaluating Structural Equation Models with Unobservable Variables and Measurement Error. Journal of Marketing Research, 18(1), 39-50.

Furumo, K., de Pillis, E., \& Buxton, M. (2012). The Impact of Leadership on 
Participation and Trust in Virtual Teams. Paper Presented at the Proceedings of the 50th Annual Conference on Computers and People Research.

Gallup, I. (2011). Employee Engagement-A Leading Indicator of Financial Performance. Gallup Corporate Website.

Gillet, N., Huart, I., Colombat, P., \& Fouquereau, E. (2013). Perceived Organizational Support, Motivation, and Engagement Among Police Officers. Professional Psychology: Research and Practice, 44(1), 46-55.

Gruman, J. A., \& Saks, A. M. (2011). Performance Management and Employee Engagement. Human Resource Management Review, 21(2), 123-136.

Hair Jr, J. F., Hult, G. T. M., Ringle, C., \& Sarstedt, M. (2016). A Primer on Partial Least Squares Structural Equation Modeling (PLS-SEM): Sage Publications.

Hassan, A., \& Ahmed, F. (2011). Authentic Leadership, Trust and Work Engagement. International Journal of Human and Social Sciences, 6(3), 164-170.

He, H., Zhu, W., \& Zheng, X. (2014). Procedural justice and Employee Engagement: Roles of Organizational Identification and Moral Identity Centrality. Journal of Business Ethics, 122(4), 681-695.

Heslin, P. A. (2010). Mindsets and Employee Engagement: Theoretical Linkages and Practical Interventions. Handbook of Employee Engagement: Perspectives, issues, Research and Practice, 218.

Hirschi, A., Lee, B., Porfeli, E. J., \& Vondracek, F. W. (2013). Proactive Motivation and Engagement in Career Behaviors: Investigating Direct, Mediated, and Moderated Effects. Journal of Wocational Behavior, 83(1), 31-40.

Holland, P., Cooper, B., \& Sheehan, C. (2017). Employee Voice, Supervisor Support, and Engagement: The Mediating Role of Trust. Human Resource Management, 56(6), 915-929.

Huhtala, M., \& Feldt, T. (2016). The Path from Ethical Organisational Culture to Employee Commitment: Mediating Roles of Value Congruence and Work Engagement. Scandinavian Journal of Work and Organizational Psychology, 1(1), 3-14.

Inceoglu, I., \& Fleck, S. (2010). Engagement as a Motivational Construct: New Horizons in Management. Handbook of Employee Engagement: Perspectives, Issues, Research and Practice (pp. 74-86). Northampton, MA, US: Edward Elgar Publishing.

Janićijević, N. (2013). The Mutual Impact of Organizational Culture and Structure. Economic Annals, 58(198), 35-60.

Jung, D. I., Chow, C., \& Wu, A. (2003). The Role of Transformational Leadership in Enhancing Organizational Innovation: Hypotheses and some Preliminary Findings. The Leadership Quarterly, 14(4-5), 525-544.

Kahn, W. A. (1990). Psychological Conditions of Personal Engagement and Disengagement at Work. Academy of Management Journal, 33(4), 692-724.

Kalshoven, K., Den Hartog, D. N., \& De Hoogh, A. H. (2011). Ethical Leadership at Work Questionnaire (ELW): Development and Validation of a Multidimensional Measure. The Leadership Quarterly, 22(1), 51-69.

Karanges, E., Johnston, K., Beatson, A., \& Lings, I. (2015). The Influence of Internal Communication on Employee Engagement: A Pilot Study. Public Relations Review, 41(1), 129-131.

Keating, L. A., \& Heslin, P. A. (2015). The Potential Role of Mindsets in Unleashing 
Employee Engagement. Human Resource Management Review, 25(4), 329-341.

Krishnan, S. K., \& Singh, M. (2010). Outcomes of Intention to Quit of Indian IT Professionals. Human Resource Management: Published in Cooperation with the School of Business Administration, The University of Michigan and in Alliance with the Society of Human Resources Management, 49(3), 421-437.

Kuoppala, J., Lamminpää, A., Liira, J., \& Vainio, H. (2008). Leadership, Job WellBeing, and Health Effects-A Systematic Review and a Meta-Analysis. Journal of Occupational Environmental Medicine, 50(8), 904-915.

Lambert, E. G., Paoline III, E. A., \& Hogan, N. L. (2006). The Impact of Centralization and Formalization on Correctional Staff Job Satisfaction and Organizational Commitment: An Exploratory Study. Criminal Justice Studies, 19(1), 23-44.

Lawshe, C. H. (1975). A Quantitative Approach to Content Validity. Personnel Psychology, 28(4), 563-575.

Lee, C., Kang, H.-g., \& Seok, W. (2018). How Does Organizational Structure Affect Executive Compensation? Applied Economics Letters, 25(6), 405-408.

Leeds, J. P., \& Nierle, D. (2014). Engaging in Healthy Debate Over Employee Engagement. Public Manager, 43(4), 61-64.

Lyu, X. (2016). Effect of Organizational Justice on Work Engagement with Psychological Safety as a Mediator: Evidence from China. Social Behavior and Personality: An International Journal, 44(8), 1359-1370.

Macey, W. H., \& Schneider, B. (2008). The Meaning of Employee Engagement. Industrial Organizational Psychology, 1(1), 3-30.

Macey, W. H., Schneider, B., Barbera, K. M., \& Young, S. A. (2009). Employee Engagement: Tools for Analysis, Practice, and Competitive Advantage: Wiley Online Library.

Mangundjaya, W.L.(2012). Are Organizational Commitment and Employee Engagement Important in Achieving Individual Readiness for Change? HUMANITAS (Jurnal Psikologi Indonesia), 9(2), 185-192.

Masson, R. C., Royal, M. A., Agnew, T. G., \& Fine, S. (2008). Leveraging Employee Engagement: The Practical Implications. Industrial and Organizational Psychology, $1(1), 56-59$.

May, D. R., Gilson, R. L., \& Harter, L. M. (2004). The Psychological Conditions of Meaningfulness, Safety and Availability and the Engagement of the Human Spirit at Work. Journal of Occupational Organizational Psychology, 77(1), 11-37.

Menguc, B., Auh, S., Fisher, M., \& Haddad, A. (2013). To be engaged or not to be engaged: The Antecedents and Consequences of Service Employee Engagement. Journal of Business Research, 66(11), 2163-2170

Meyer, J., \& Allen, N. (1997). Commitment in the Workplace Thousand Oaks: Sage Publications.

Mishra, K., Boynton, L., \& Mishra, A. (2014). Driving Employee Engagement: The Expanded Role of Internal Communications. International Journal of Business Communication, 51(2), 183-202.

Mitroff, I. I., \& Denton, E. A. (1999). A study of spirituality in the workplace. Sloan management review, 40(4), 83-104.

Mohapatra, M., \& Sharma, B. R. (2010). Study of Employee Engagement and its Predictors in an Indian Public Sector Undertaking. Global Business Review, 11(2), 
281-301.

Mukherjee, A., \& Malhotra, N. t. (2006). Does Role Clarity Explain EmployeePerceived Service Quality? A Study of Antecedents and Consequences in Call Centres. International Journal of Service Industry Management, 17(5), 444-473.

Nahrgang, J. D., Morgeson, F. P., \& Hofmann, D. A. (2011). Safety at Work: A MetaAnalytic Investigation of the Link between Job Demands, Job Resources, Burnout, Engagement, and Safety Outcomes. Journal of Applied Psychology, 96(1), 71.

Nair, M. S., \& Salleh, R. (2015). Linking Performance Appraisal Justice, Trust, and Employee Engagement: A Conceptual Framework. Procedia-Social and Behavioral Sciences, 211(1), 1155-1162.

Ng, K.-Y., Ang, S., \& Chan, K.-Y. (2008). Personality and Leader Effectiveness: A Moderated Mediation Model of Leadership Self-Efficacy, Job Demands, and Job Autonomy. Journal of Applied Psychology, 93(4), 733-743.

Niehoff, B. P., \& Moorman, R. H. (1993). Justice as a Mediator of the Relationship between Methods of Monitoring and Organizational Citizenship Behavior. Academy of Management Journal, 36(3), 527-556.

Nimon, K., Shuck, B., \& Zigarmi, D. (2016). Construct Overlap between Employee Engagement and Job Satisfaction: A Function of Semantic Equivalence? Journal of Happiness Studies, 17(3), 1149-1171.

Park, J., \& Gursoy, D. (2012). Generation Effects on work Engagement Among US Hotel Employees. International Journal of Hospitality Management, 31(4), 1195-1202.

Park, Y., Song, J. H., \& Lim, D. H. (2016). Organizational Justice and Work Engagement: The Mediating Effect of Self-Leadership. Leadership Organization Development Journal, 37(6), 711-729.

Pati, S. P., \& Kumar, P. (2010). Employee Engagement: Role of Self-Efficacy, Organizational Support \& Supervisor Support. Indian Journal of Industrial Relations, 46(1), 126-137.

Pemecutan, A. A. G. G., Dharmanegara, I. B. A., \& Udayana, I. G. B. (2016). The Role of Perceived Organizational Support to Increase Effect of Organizational Justice Dimension on Organizational Citizenship Behavior. IOSR Journal of Business and Management, 18(8), 57-68.

Prasanna, T., \& Swarnalatha, C. (2018). Increasing Organizational Commitment of Employees: By Correlation of Goal Setting, Employee Engagement and Optimism in the Organization. International Journal of Advances in Management Economics, 1(6), 40-44.

Purcell, J. (2003). Understanding the People and Performance Link: Unlocking the Black Box: CIPD Publishing.

Raza, M. Y., Akhtar, M. W., Husnain, M., \& Akhtar, M. S. (2015). The Impact of Intrinsic Motivation on Employee's Job Satisfaction. Management and Organizational Studies, 2(3), 80-88.

Reed, H. (2016). Goal Setting and Engagement: An Exploration of Vigor, Dedication, and Absorption in the Workplace. The University of the Rockies.

Rego, A., \& Pina e Cunha, M. (2008). Workplace Spirituality and Organizational Commitment: An Empirical Study. Journal of Organizational Change Management, 21(1), 53-75.

Robinson, D., Perryman, S., \& Hayday, S. (2004). The Drivers of Employee Engagement. Report-Institute for Employment Studies. 
Robinson, I. (2006). Human Resource Management in Organisations: The Theory and Practice of High Performance: Chartered Institute of Personnel and Development.

Roof, R. A. (2015). The Association of Individual Spirituality On Employee Engagement: The Spirit at Work. Journal of Business Ethics, 130(3), 585-599.

Runhaar, P., Konermann, J., \& Sanders, K. (2013). Teachers' Organizational Citizenship Behaviour: Considering the Roles of Their Work Engagement, Autonomy and Leader-Member Exchange. Teaching and Teacher Education, 30(1), 99-108.

Ruyle, K., Eichinger, R., \& DeMeuse, K. (2009). FYI for Talent Engagement: Drivers of Best Practice for Managers and Business Leaders. Minneapolis, MN: Korn/Ferry International.

Saks, A. M. (2006). Antecedents and Consequences of Employee Engagement. Journal of Managerial Psychology, 21(7), 600-619.

Salanova, M., \& Schaufeli, W. B. (2008). A Cross-National Study of Work Engagement As a Mediator between Job Resources and Proactive Behaviour. The International Journal of Human Resource Management, 19(1), 116-131.

Sawyer, J. E. (1992). Goal and Process Clarity: Specification of Multiple Constructs of Role Ambiguity and a Structural Equation Model of Their Antecedents and Consequences. Journal of Applied Psychology 77(1), 130-142.

Seifert, R., \& Tegg, V. (1998). Management Development in the British and Irish Civil Services. Journal of Management Development, 17(9), 686-698.

Storey, J., Wright, P. M., \& Ulrich, D. (2009). The Routledge Companion to Strategic Human Resource Management: Taylor \& Francis.

Schaufeli, W., \& Bakker, A. (2003). UWES-Utrecht Work Engagement Scale: Test Manual. Unpublished Manuscript: Department of Psychology, Utrecht University, 8.

Schaufeli, W., Taris, T., Le Blanc, P., Peeters, M., Bakker, A., \& De Jonge, J. (2001). Maakt Arbeid Gezond. Op Zoek Naar de Bevlogen Werknemer, Does Work Make Happy, 422-428.

Schaufeli, W. B., Bakker, A. B., \& Salanova, M. (2006). The Measurement of Work Engagement with a Short Questionnaire: A Cross-National Study. Educational Psychological Measurement, 66(4), 701-716.

Shimazu, A., Schaufeli, W., Kosugi, S., Suzuki, A., Nashiwa, H., Kato, A., . . Hirohata, K. (2008). Work Engagement in Japan: Validation of the Japanese Version of the Utrecht Work Engagement Scale. Applied Psychology, 57(3), 510-523.

Shoemaker, M. E. (2003). Leadership Behaviors in Sales Managers: A Level Analysis. Journal of Marketing Theory and Practice, 11(2), 17-29.

Shuck, B., \& Albornoz, C. (2007). Below the Salary Line: Employee Engagement of Non-Salaried Employees. Online Submission.

Shuck, B., \& Wollard, K. (2010). Employee Engagement and HRD: A Seminal Review of the Foundations. Human Resource Development Review, 9(1), 89-110.

Soane, E., Truss, C., Alfes, K., Shantz, A., Rees, C., \& Gatenby, M. (2012). Development and Application of a New Measure of Employee Engagement: The ISA Engagement Scale. Human Resource Development International, 15(5), 529-547.

Spagnoli, P., \& Caetano, A. (2012). Personality and Organisational Commitment: The Mediating Role of Job Satisfaction During Socialisation. Career Development International, 17(3), 255-275.

Storm, K., \& Rothmann, S. (2003). A Psychometric Analysis of the Utrecht Work 
Engagement Scale in the South African Police Service. SA Journal of Industrial Psychology, 29(4), 62-70.

Thakur, P. (2014). A Research Paper on the Effect of Employee Engagement on Job Satisfaction in IT Sector. Journal of Business Management Social Sciences Research, 3(5), 31-39.

Tims, M., Bakker, A. B., \& Xanthopoulou, D. (2011). Do Transformational Leaders Enhance Their Followers' Daily Work Engagement? The Leadership Quarterly, 22(1), 121-131.

Top, M., Akdere, M., \& Tarcan, M. (2015). Examining Transformational Leadership, Job Satisfaction, Organizational Commitment and Organizational Trust in Turkish Hospitals: Public Servants Versus Private Sector Employees. The International Journal of Human Resource Management, 26(9), 1259-1282.

Wang, D.-S., \& Hsieh, C.-C. (2013). The Effect of Authentic Leadership on Employee Trust and Employee Engagement. Social Behavior and Personality: An International Journal, 41(4), 613-624.

Wildermuth, S. A. (2008). Cognitive Behavioral Group Therapy for Adolescents with Type I Diabetes: Regent University.

Woods, S. A., \& Sofat, J. A. (2013). Personality and Eengagement at Work: The Mediating Role of Psychological Meaningfulness. Journal of Applied Social Psychology, 43(11), 2203-2210.

Xanthopoulou, D., Bakker, A. B., Demerouti, E., \& Schaufeli, W. B. (2009). Reciprocal Relationships Between Job Resources, Personal Resources, and Work Engagement. Journal of Vocational Behavior, 74(3), 235-244.

Yi-wen, Z., \& Yi-qun, C. (2005). The Chinese Version of Utrecht Work Engagement Scale: An Examination of Reliability and Validity. Chinese Journal of Clinical Psychology, 13(3), 268-270.

Zenoff, D. B. (2014). The Soul of the Organization: How to Ignite Employee Engagement and Productivity at Every Level: Apress. 
جدول الف: بررسى ڤايايع و روايى مدل ثئوهش

\begin{tabular}{|c|c|c|c|c|}
\hline روايى تشخيصى & $\begin{array}{c}\text { روايى همكرا } \\
\text { (AVE) }\end{array}$ & $\begin{array}{l}\text { هايايى مركب } \\
\text { (CR) }\end{array}$ & آلفاى كرونباخ & متغير مكنون \\
\hline بلى بل & $\cdot / V A \mid$ & $\cdot / 9 \cdot 0$ & - /AFV & امنيت شغلى \\
\hline 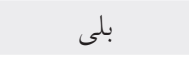 & $\cdot / \mathrm{N} \Lambda$ &.$/ 9 k 4$ & $\cdot / 9 r \wedge$ & انخيزش درونى \\
\hline 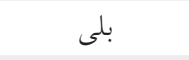 & $\cdot / V 99$ & $\cdot / 9 \cdot 9$ & $\cdot / \wedge \Delta$ & بازخورد سازنده \\
\hline بلى بلى & $\cdot / 0199$ & $\cdot / 111$ & $\cdot / V Y$ & شخصيت (برونگرايى) \\
\hline بلى بلى & $\cdot / \Lambda \cdot r$ & . /9YK & -/AVG & اعتماد سازمانى \\
\hline بلى بلى & - NGK & $\cdot / 9 \cdot 0$ &.$/ 991$ & التزام رفتارى كاركنان \\
\hline 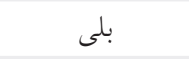 & $\cdot / 111$ & $\cdot / 99 \mathrm{~V}$ &.$/ 9 \ldots$ & ارتباط با بالادستى \\
\hline 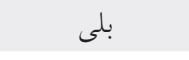 & • & - /MA & . NVY & استقلال كارى \\
\hline بلى بل & •/ATQ & $\cdot / 9 \mu \wedge$ &.$/ 919$ & اعتماد سازمانى \\
\hline بلى بلى & . /GTt & $\cdot / \mathrm{VqV}$ & $\cdot / \mathrm{VT}$. & فرهنگ همكارى \\
\hline 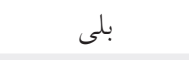 & $\cdot / 219$ & $\cdot / 94 \wedge$ & $\cdot / v \cdot V$ & حمايت سازمانى \\
\hline 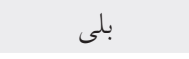 & $\cdot 1010$ & $\cdot / V Q \Delta$ & $\cdot / V^{E} \Lambda$ & جبران خدمت \\
\hline 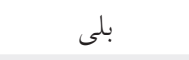 & . I9TK & •/AMI &.$/ 99 \mu$ & محيط كارى \\
\hline 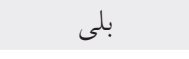 & .1999 & $\cdot / \Lambda \Delta \Delta$ & $.19 \mathrm{VT}$ & مشاركت كاركنان \\
\hline 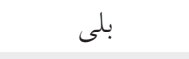 & $\cdot / A V T$ & $\cdot / 9 V 1$ & $\cdot / 1 \cdot 9$ & رهبرى اثر خذار \\
\hline 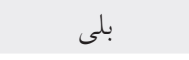 & .1919 & - IGTY & - /ATt & ساختار \\
\hline 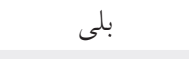 & $\cdot / D S Y$ & $.199 \Lambda$ & $\cdot / \mathrm{VIV}$ & تعهد سازمانى \\
\hline 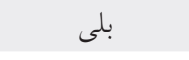 & $\cdot$ /VYA & - /MA9T & $.19 \Lambda$ & تعصب دينى \\
\hline بلى & $\cdot / 09 \mathrm{~V}$ & . MTr & $\cdot|A| \mid$ & وضوح نقش \\
\hline
\end{tabular}

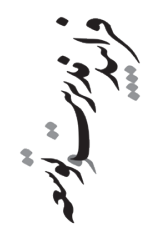


جدول ب: بروسى آزمون كيفيت مدل در نرمافزار PLS

\begin{tabular}{|c|c|c|}
\hline $\begin{array}{l}\text { CV Red. } \\
\text { 1-SSE/SSO }\end{array}$ & $\begin{array}{c}\text { CV Com. } \\
\text { 1-SSE/SSO }\end{array}$ & متغير \\
\hline • MTrATL & $\cdot / \Delta \cdot \Delta V V q$ & امنيت شغلى \\
\hline.$/ \cdot 1 \wedge 901$ & $\cdot / N T \Lambda \cdot T Q$ & انخيزش درونى \\
\hline - /9N9MMr & - /9人9MNA & بازخورد سازنده \\
\hline$\cdot / 144919$ & $\cdot 1 / 449919$ & شخصيت (برون كرايى) \\
\hline . / TSOQYV &.$/ T 909 Y \mathrm{~V}$ & اعتماد سازمانى \\
\hline - N. MGGY & - N. MGG4 & التزام رفتارى كاركنان \\
\hline •/NVq0Ka & •/NVq0Ts & ارتباط با بالادستى \\
\hline - /9VIYAG & ./GVTYA & استقلال كارى \\
\hline - IVtora & $\cdot / 1 \cdot 9940$ & اعتماد سازمانى \\
\hline .1 1 YDQSG & - NYAATI & فرهنخ همكارى \\
\hline - MYAgY4a & - /v91VI9 & حمايت سازمانى \\
\hline . MT. QTG & $\cdot|A \& V \cdot \Delta|$ & جبران خدمت \\
\hline • MDYAQT & .1999090 & محيط كارى \\
\hline .1 .99149 & $\cdot / 0 \cdot 9 \wedge \mathrm{VT}$ & مشاركت كاركنان \\
\hline •/ITAKNI & .19194 .9 & رهبرى اثر كذار \\
\hline - TAGGYG & $\cdot / O H K V \cdot \Lambda$ & ساختار \\
\hline - /va.var & - /va.var & تعهد سازمانى \\
\hline - Mrenki & - NREANI & تعصب دينى \\
\hline $.1 .94 k$ Kr & - Mrgq4aI & وضوح نقش \\
\hline
\end{tabular}

